\title{
Microstructure, Mechanical Properties and Wear Behavior of the Rheoformed 2024 Aluminum Matrix Composite Component Reinforced by $\mathrm{Al}_{2} \mathrm{O}_{3}$ Nanoparticles
}

\author{
Jufu Jiang ${ }^{1, *}$, Guanfei Xiao ${ }^{1}$, Changjie Che ${ }^{1}$ and Ying Wang ${ }^{2}$ \\ 1 School of Materials Science and Engineering, Harbin Institute of Technology, Harbin 150001, China; \\ guanfeixiao@163.com (G.X.); 18092233726@163.com (C.C.) \\ 2 School of Mechatronics Engineering, Harbin Institute of Technology, Harbin 150001, China; \\ wangying1002@hit.edu.cn \\ * Correspondence: jiangjufu@hit.edu.cn; Tel.: +86-187-4601-3176
}

Received: 3 May 2018; Accepted: 14 June 2018; Published: 15 June 2018

\begin{abstract}
The 2024 nanocomposite reinforced with $\mathrm{Al}_{2} \mathrm{O}_{3}$ nanoparticles was fabricated by the ultrasonic assisted semisolid stirring (UASS) method and rheoformed into a cylinder component. Microstructure, mechanical properties, and wear behavior of the rheoformed composite components were investigated. The results showed that the composite components with complete filling status and a good surface were rheoformed successfully. The deformation of semisolid slurries was mainly dominated by flow of liquid incorporating solid grains (FLS), sliding between solid grains (SSG), and plastic deformation of solid grains (PDS). Mechanical properties of the rheoformed composite components were influenced by stirring temperature, stirring time, and volume fraction of $\mathrm{Al}_{2} \mathrm{O}_{3}$ nanoparticles. The optimal ultimate tensile strength (UTS) of $358 \mathrm{MPa}$ and YS of $245 \mathrm{MPa}$ were obtained at the bottom of the rheoformed composite components after a 25-min stirring of composite semisolid slurry with $5 \% \mathrm{Al}_{2} \mathrm{O}_{3}$ nanoparticles at $620{ }^{\circ} \mathrm{C}$. Enhancement of mechanical properties was attributed to high density dislocations and dislocation tangles and uniform dispersed $\mathrm{Al}_{2} \mathrm{O}_{3}$ nanoparticles in the aluminum matrix. Natural ageing led to the occurrence of needle-like $\mathrm{Al}_{2} \mathrm{CuMg}$ phase and short-rod-like $\mathrm{Al}_{2} \mathrm{Cu}$ phase. UTS of $417 \mathrm{MPa}$ and YS of $328 \mathrm{MPa}$ of the rheoformed composite components were achieved after $\mathrm{T} 6$ heat treatment. Improvement of mechanical properties is due to the more precipitated needle-like $\mathrm{Al}_{2} \mathrm{CuMg}$ phase and short-rod-like $\mathrm{Al}_{2} \mathrm{Cu}$ phase. Wear resistance of the rheoformed composite components was higher than that of the rheoformed matrix component. Wear resistance of the rheoformed composite component increased with an increase in $\mathrm{Al}_{2} \mathrm{O}_{3}$ nanoparticles from $1 \%$ to $7 \%$. A slight decrease in wear rate resulted from $10 \% \mathrm{Al}_{2} \mathrm{O}_{3}$ nanoparticles due to greater agglomeration of $\mathrm{Al}_{2} \mathrm{O}_{3}$ nanoparticles. A combination mechanism of adhesion and delamination was determined according to worn surface morphology.
\end{abstract}

Keywords: 2024 aluminum matrix composites; rheoformed; $\mathrm{Al}_{2} \mathrm{O}_{3}$ nanoparticles; microstructure; mechanical properties

\section{Introduction}

Metal matrix composites (MMC) have exhibited some obvious advantages such as high specific strength, high specific stiffness, and good wear resistance [1-3]. Fabrication technology of MMC involves stirring casting [4,5], powder metallurgy [6-8], squeeze casting [9-11], and semisolid stirring [12-14]. In addition, selective laser melting (SLM) was employed to fabricate high-performance alloys and MMC [15-17]. As a typical MMC, aluminum matrix composite reinforced by ceramic 
particles (AMCCP) also exhibited some important applications in the automotive and aerospace industries [18,19]. The reinforced ceramic particles are composed of micro-sized ceramic particles and nano-sized ceramic particles. In recent years, aluminum matrix composites reinforced with nano-sized ceramic particles (AMCNCP) have attracted researchers' attention because of higher strength, increased dimensional stability, high thermal stability, high modulus, and good wear resistance as compared to conventional materials [20]. Raju et al. [21] evaluated fatigue of nano-sized $\mathrm{Al}_{2} \mathrm{O}_{3 p} / 2024$ composite and found that it was slightly increased as compared to matrix material. Raturi et al. [22] reported mechanical, tribological, and micro structural behavior of the Al 7075 matrix reinforced with nano $\mathrm{Al}_{2} \mathrm{O}_{3}$ particles and concluded that tensile, impact, and flexural strength of the composite were enhanced as compared with the matrix alloy. Sajjadi et al. [23] investigated the fabrication and mechanical properties of $\mathrm{A} 356$ composite reinforced with micro and nano-sized $\mathrm{Al}_{2} \mathrm{O}_{3}$ particles by a developed compocasting method. The results showed that the hardness of the composites increased with increasing particle weight fraction and decreasing particle size.

However, it is very difficult to disperse uniformly nano-sized ceramic particles in the matrix alloy due to higher surface energy and specific surface area as compared to micro-sized ceramic particles. Therefore, some novel methods were developed to realize uniform dispersion of nano-sized ceramic particles such as $\mathrm{Al}_{2} \mathrm{O}_{3}$ and $\mathrm{SiC}$. For example, uniform dispersion of $\mathrm{Al}_{2} \mathrm{O}_{3}$ nanoparticles in matrix alloy was achieved successfully via incorporating milled powders of $\mathrm{Al}_{2} \mathrm{O}_{3}$ nanoparticles and aluminum or copper into A356 alloy melt [24,25]. Acoustic streaming and cavitation created by ultrasonic wave led to a uniform dispersion of nano-sized SiC particles in molten A356 aluminum alloy [26,27]. Semisolid stirring and ultrasonic wave were joined together to obtain a uniform dispersion of nano-sized $\mathrm{SiC}$ particles in 7075 aluminum matrix. It was attributed to the controllable viscosity of semisolid slurries and acoustic streaming and cavitation created by ultrasonic wave [28].

Matrix materials of AMCNCP mainly have been focused on A356 [24-27], 7075 [28], A357 [29], and 6061 [8] aluminum alloys, but 2024 matrix material has not been studied in detail. The present investigation will deal with microstructure and mechanical properties of 2024 aluminum matrix composite reinforced with $\mathrm{Al}_{2} \mathrm{O}_{3}$ nanoparticles.

\section{Materials and Methods}

\subsection{Fabrication of 2024 Aluminum Matrix Composite Reinforced with $\mathrm{Al}_{2} \mathrm{O}_{3}$ Nanoparticles}

Commercial 2024 aluminum alloy was used as matrix material. Its chemical composition was determined via an Axios pw4400 X-ray fluorescence spectrometer and contained $4.52 \mathrm{wt} \%$ $\mathrm{Cu}, 1.51 \mathrm{wt} \% \mathrm{Mg}, 0.56 \mathrm{wt} \% \mathrm{Mn}, 0.18 \mathrm{Si}$ wt \%, $0.12 \mathrm{wt} \% \mathrm{Fe}, 0.02 \mathrm{wt} \% \mathrm{Zn}$, and a balance of Al. $\alpha-\mathrm{Al}_{2} \mathrm{O}_{3}$ nanoparticles with an average size of $60 \mathrm{~nm}$ were used as reinforcement of the composite. Solidus temperature of $529^{\circ} \mathrm{C}$ and liquidus temperature of $650^{\circ} \mathrm{C}$ were achieved from a differential scanning calorimetry (DSC) test. Figure 1 gives a schematic diagram of fabrication and rheoforming of 2024 matrix composite semisolid slurry. As shown in Figure 1, there were three main procedures in the fabrication and rheoforming of composite semisolid slurry. In the first procedure, $\alpha-\mathrm{Al}_{2} \mathrm{O}_{3}$ nanoparticles with an average size of $60 \mathrm{~nm}$ parceled by pure aluminum foil were added into the melt after 2024 aluminum alloy was melted at $670{ }^{\circ} \mathrm{C}$ and held for $20 \mathrm{~min}$. The XRD pattern of as-received $\mathrm{Al}_{2} \mathrm{O}_{3}$ nanoparticles shows the presence of $\alpha-\mathrm{Al}_{2} \mathrm{O}_{3}$ peaks (Figure 2). The melt with $\alpha-\mathrm{Al}_{2} \mathrm{O}_{3}$ nanoparticles was treated for $10 \mathrm{~min}$ via an ultrasonic device. In the second procedure, melt with $\alpha-\mathrm{Al}_{2} \mathrm{O}_{3}$ nanoparticles was stirred and cooled to the predefined semisolid temperature, and then isothermally stirred for the required time, as shown in Table 1. 


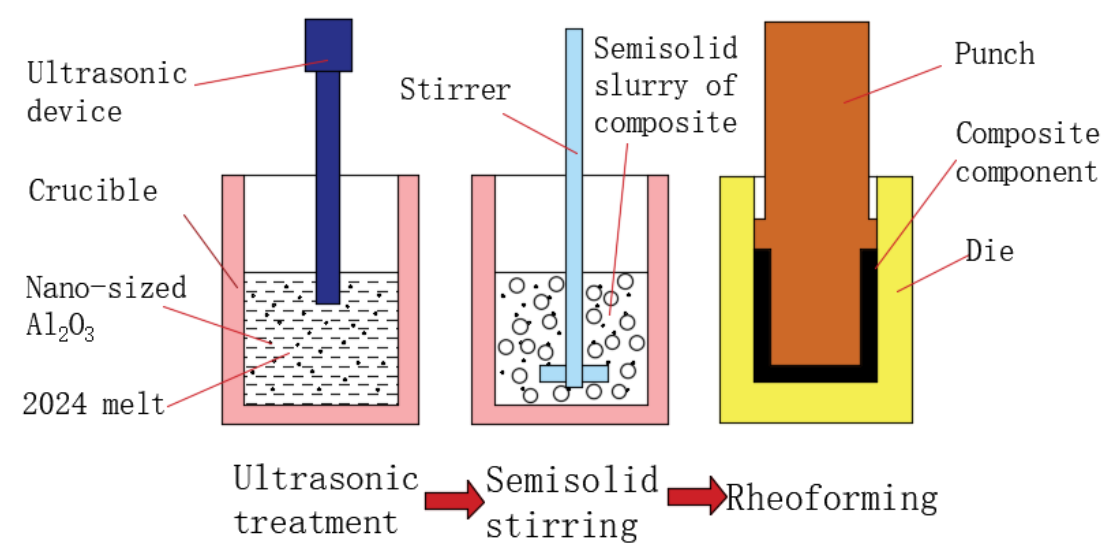

Figure 1. Schematic diagram of fabricating and rheoforming the semisolid slurry of composite.

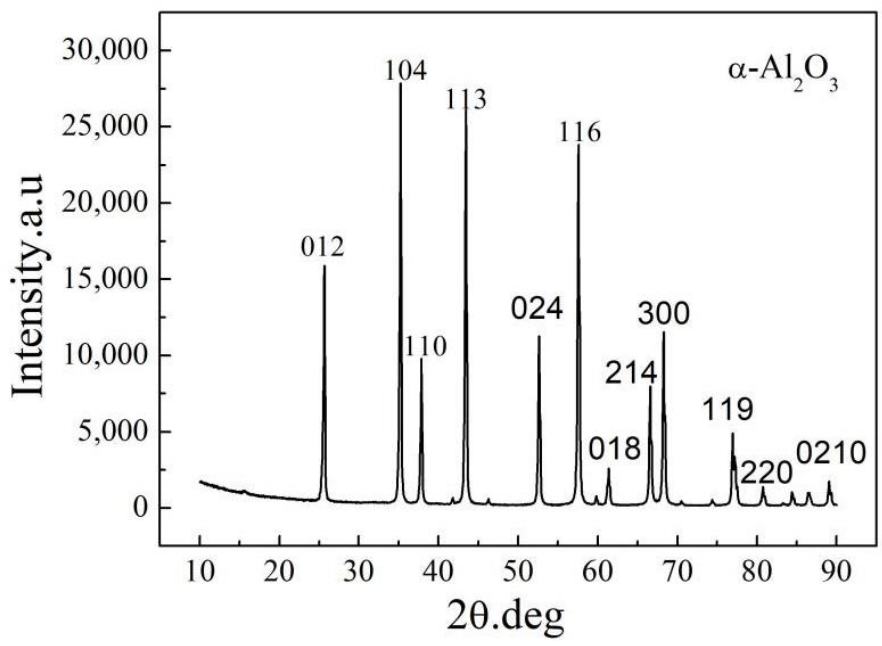

Figure 2. XRD pattern of as-received $\mathrm{Al}_{2} \mathrm{O}_{3}$ nanoparticles.

Table 1. Experimental scheme of the rheoformed 2024 aluminum matrix composite reinforced by $\mathrm{Al}_{2} \mathrm{O}_{3}$ nanoparticles and original 2024 components.

\begin{tabular}{|c|c|c|c|c|c|c|c|}
\hline $\begin{array}{l}\text { Serial } \\
\text { Number }\end{array}$ & $\begin{array}{c}\text { Stirring } \\
\text { Time (Min) }\end{array}$ & $\begin{array}{c}\text { Stirring } \\
\text { Temperature } \\
\left({ }^{\circ} \mathrm{C}\right)\end{array}$ & $\mathrm{Al}_{2} \mathrm{O}_{3}$ Volume Fraction & $\begin{array}{c}\text { Ultrasonic } \\
\text { Treatment Time } \\
\text { (Min) }\end{array}$ & Force $(\mathbf{k N})$ & $\begin{array}{l}\text { Dwell Time } \\
\text { (s) }\end{array}$ & $\begin{array}{c}\text { Preheated } \\
\text { Temperature of Die } \\
\left({ }^{\circ} \mathrm{C}\right)\end{array}$ \\
\hline 1 & 5 & 620 & 5 & 10 & 2000 & 20 & 400 \\
\hline 2 & 10 & 620 & 5 & 10 & 2000 & 20 & 400 \\
\hline 3 & 15 & 620 & 5 & 10 & 2000 & 20 & 400 \\
\hline 5 & 20 & 620 & 5 & 10 & 2000 & 20 & 400 \\
\hline 6 & 25 & 620 & 5 & 10 & 2000 & 20 & 400 \\
\hline 7 & 30 & 620 & 5 & 10 & 2000 & 20 & 400 \\
\hline 8 & 25 & 610 & 5 & 10 & 2000 & 20 & 400 \\
\hline 9 & 25 & 615 & 5 & 10 & 2000 & 20 & 400 \\
\hline 10 & 25 & 625 & 5 & 10 & 2000 & 20 & 400 \\
\hline 11 & 25 & 630 & 5 & 10 & 2000 & 20 & 400 \\
\hline 12 & 25 & 620 & 0 & 10 & 2000 & 20 & 400 \\
\hline 13 & 25 & 620 & 1 & 10 & 2000 & 20 & 400 \\
\hline 14 & 25 & 620 & 3 & 10 & 2000 & 20 & 400 \\
\hline 15 & 25 & 620 & 7 & 10 & 2000 & 20 & 400 \\
\hline 16 & 25 & 620 & 10 & 10 & 2000 & 20 & 400 \\
\hline 17 & 25 & 610 & 0 & 10 & 2000 & 20 & 400 \\
\hline 18 & 25 & 615 & 0 & 10 & 2000 & 20 & 400 \\
\hline 19 & 25 & 625 & 0 & 10 & 2000 & 20 & 400 \\
\hline 20 & 25 & 630 & 0 & 10 & 2000 & 20 & 400 \\
\hline
\end{tabular}

In the third procedure, the fabricated semisolid slurries of the composite were carried directly into the die cavity with a preheated temperature of $400{ }^{\circ} \mathrm{C}$ and rheoformed (i.e., semisolid slurry was directly formed into the final part under some pressure) under a force of $2000 \mathrm{kN}$. The detailed 
experimental scheme was shown in Table 1. Two composite components under the same process parameters were rheoformed in order to improve the accuracy of tensile test. Therefore, thirty composite components were rheoformed successfully. Ten original 2024 components without $\mathrm{Al}_{2} \mathrm{O}_{3}$ nanoparticles were also rheoformed in order to compare microstructure, mechanical properties, and wear behavior with composite components.

\subsection{Microstructure Observation and Measurement of Mechanical and Wear Properties}

The microstructural specimens cut from composite components were firstly ground with 200, 400, $600,800,1200$, and 2000 grit papers and then polished with $0.1 \mu \mathrm{m}$ diamond paste. The specimens were etched for about $10 \mathrm{~s}$ by Keller's reagent ( $4 \mathrm{~mL} \mathrm{HF}, 6 \mathrm{~mL}$ HCL, $8 \mathrm{~mL}$ HNO3 and $82 \mathrm{~mL}$ water) and observed by using Olympus GX71 optical microscope (OM, Olympus Coporation, Toyko, Japan), Quanta 200 FEG scanning electron microscope (SEM, FEI, Hillsboro, OR, USA), and talos f200x transmission electron microscopy (TEM, FEI, Hillsboro, OR, USA) equipped with an energy dispersive $X$-ray spectrometer (EDX). Transmission electron microscopy specimens were fabricated via cutting $1 \mathrm{~mm}$ slices from the rheoformed composite component with a wire cutting machine, and then mechanically ground to a thickness of $100 \mu \mathrm{m}$. Then $3 \mathrm{~mm}$ diameter disks were cut from the thin slices by punching. Ion milling was carried out on these $3 \mathrm{~mm}$ diameter disks.

Tensile specimens cut from composite components were machined into standard tensile specimens according to ASTM Standard Test Methods for Tension Testing of Metallic Materials, E8M [30]. The sampled location and drawing of tensile specimens were indicated in Figure 3. Eight specimens were obtained from side wall of the two rheoformed composite components under the same process parameters and four specimens were obtained from the bottom. Four side-wall tensile specimens and two bottom specimens were directly carried out on tensile test at room temperature. The other four side-wall specimens and two bottom specimens were firstly treated via T6 heat treatment involving the solution treatment for $2 \mathrm{~h}$ at $490^{\circ} \mathrm{C}$ and ageing for $10 \mathrm{~h}$ at $190{ }^{\circ} \mathrm{C}$ and then used as a tensile test at room temperature. The tensile strength of the side wall reported in this paper was obtained from the average value of data of four side-wall specimens. The tensile strength of bottom was achieved from the average value of data of two bottom specimens. The dry sliding wear tests were carried out on a pin-on-disc wear-testing apparatus. The disc was made from $5 \mathrm{Cr} 15$ steel. After the rheoformed matrix and composite components were formed, they were machined into the samples with dimensions of $\phi 6 \times 15 \mathrm{~mm}$ for the dry sliding wear tests. The process parameters of wear test involved a distance of $1000 \mathrm{~m}$, a speed of $0.8 \mathrm{~m} / \mathrm{s}$, and a load of $30 \mathrm{~N}$.

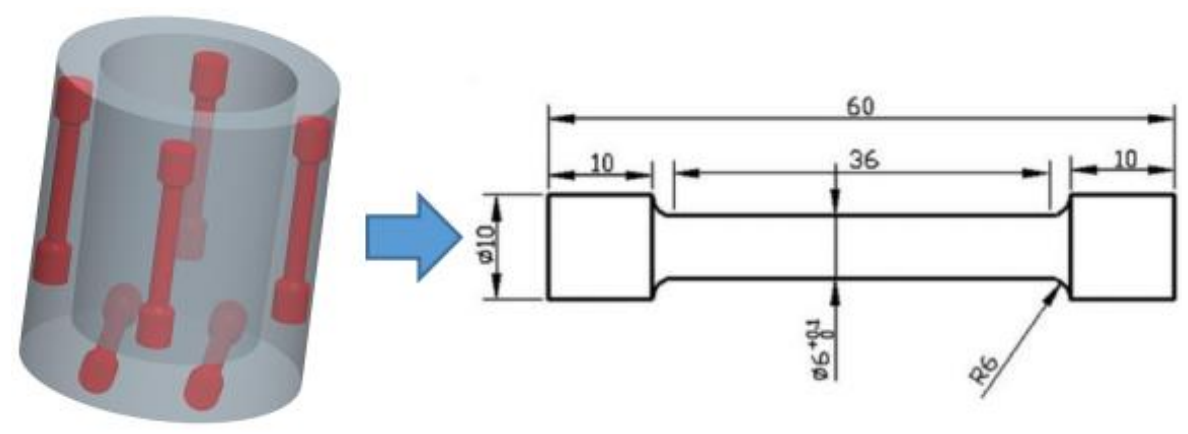

Figure 3. Sampled location and drawing of tensile specimens.

\section{Results and Discussion}

\subsection{Macrograph and Microstructure of the Rheoformed Composite Component}

Figure 4 presented the whole and half-sectional macrographs of the rheoformed composite component reinforced by $5 \mathrm{vol} \% \mathrm{Al}_{2} \mathrm{O}_{3}$ nanoparticles at $620{ }^{\circ} \mathrm{C}$ and for $25 \mathrm{~min}$ stirring time. 
As shown in Figure 4a, complete filling status and good surface quality were obtained from the rheoformed composite component. No obvious porosity and incomplete filling status were found in the half-sectional macrograph of the rheoformed composite component (Figure $4 \mathrm{~b}$ ). It illustrates that densified microstructure was obtained in the rheoformed composite components. The densified microstructure is beneficial to improve the mechancial properties of the rheoformed composite components. In order to characterize the microstructure and mechanical properties in different locations of the rheformed composite components, the microstructural specimens were achieved from the locations A to D (Figure $4 \mathrm{~b}$ ), and tensile specimens were obtained from the side wall and bottom (Figure 3).

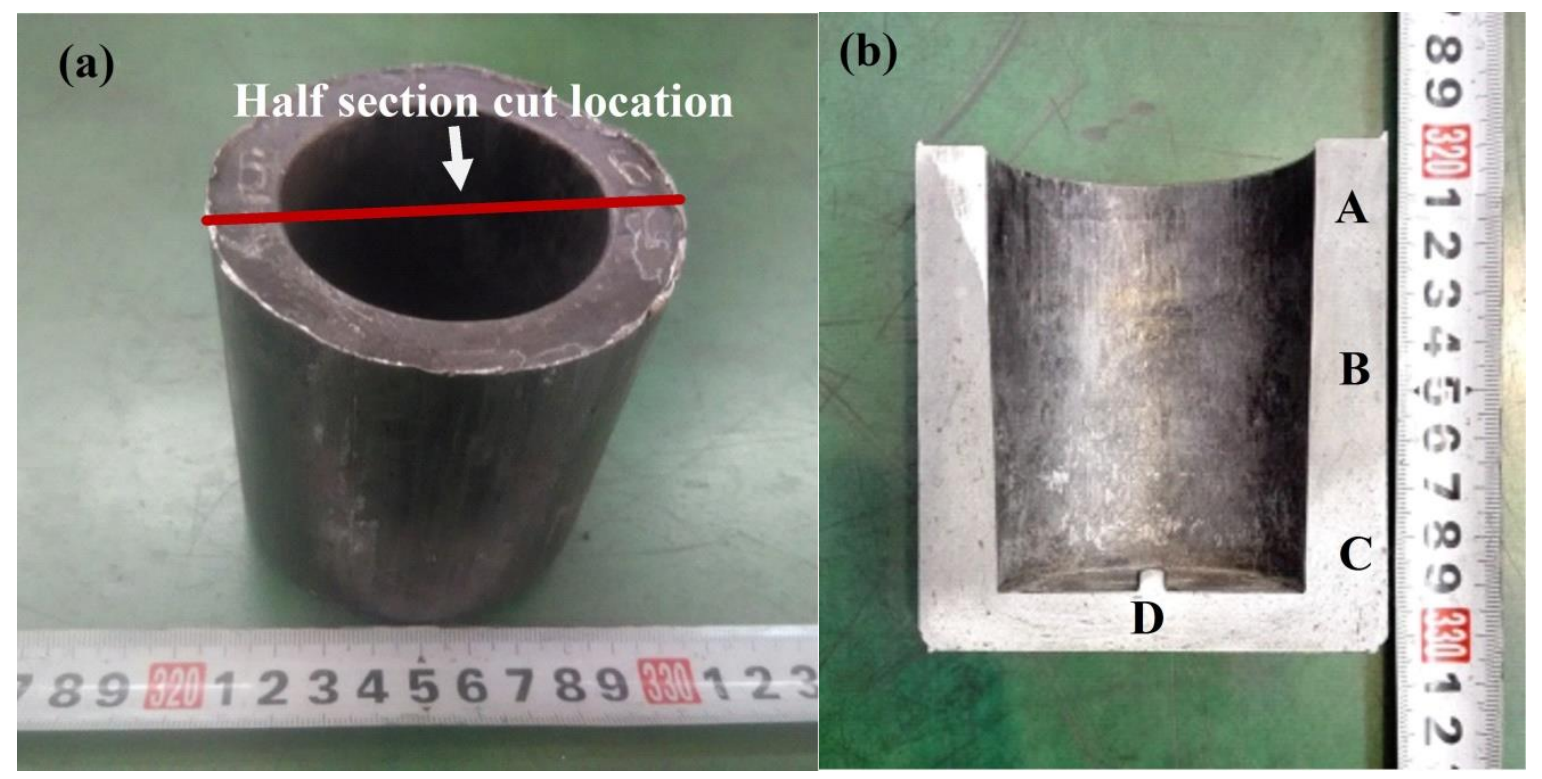

Figure 4. Whole and half-sectional macrographs of rheoformed 2024 aluminum matrix composite component reinforced by $5 \mathrm{vol} \% \mathrm{Al}_{2} \mathrm{O}_{3}$ nanoparticles at $620^{\circ} \mathrm{C}$ and for $25 \mathrm{~min}$ stirring time (a) whole macrograph; (b) half-sectional macrograph.

Microstructure in different locations of the rheoformed composite components is shown in Figure 5. As indicated in Figure 5a,b, microstructure in locations A and B consisted of near spheroidal grains and liquid phase. It illustrates that no obvious plastic deformation occurred in the solid grains in locations $\mathrm{A}$ and $\mathrm{B}$ during the rheoforming process. The microstructure in locations $\mathrm{C}$ and $\mathrm{D}$ consisted of elongated solid grains and liquid phase (Figure $5 c, d$ ). It indicates that obvious plastic deformation along flowing direction of semisolid slurries occurred in the solid grains in locations $C$ and $D$. There are four deformation mechanisms in the semisolid processing, liquid flow (LF), flow of liquid incorporating solid grains (FLS), sliding between solid grains (SSG), and plastic deformation of solid grains (PDS) [31]. When the semisolid slurry was rheoformed in the die cavity, it showed a backward extrusion mode. The flow front of the semisolid slurry in locations A and B is a free surface [27], indicating the lowest resistance to flow. The flow velocity of liquid phase is higher than that of solid phase. It led to more liquid phase existed in locations A and B. As a consequence, deformation compatibility of liquid phase is higher than that of semisolid slurry in locations $C$ and D. Therefore, deformation in locations A and B depends on flow of liquid incorporating solid grains (FLS) and sliding between solid grains (SSG). 


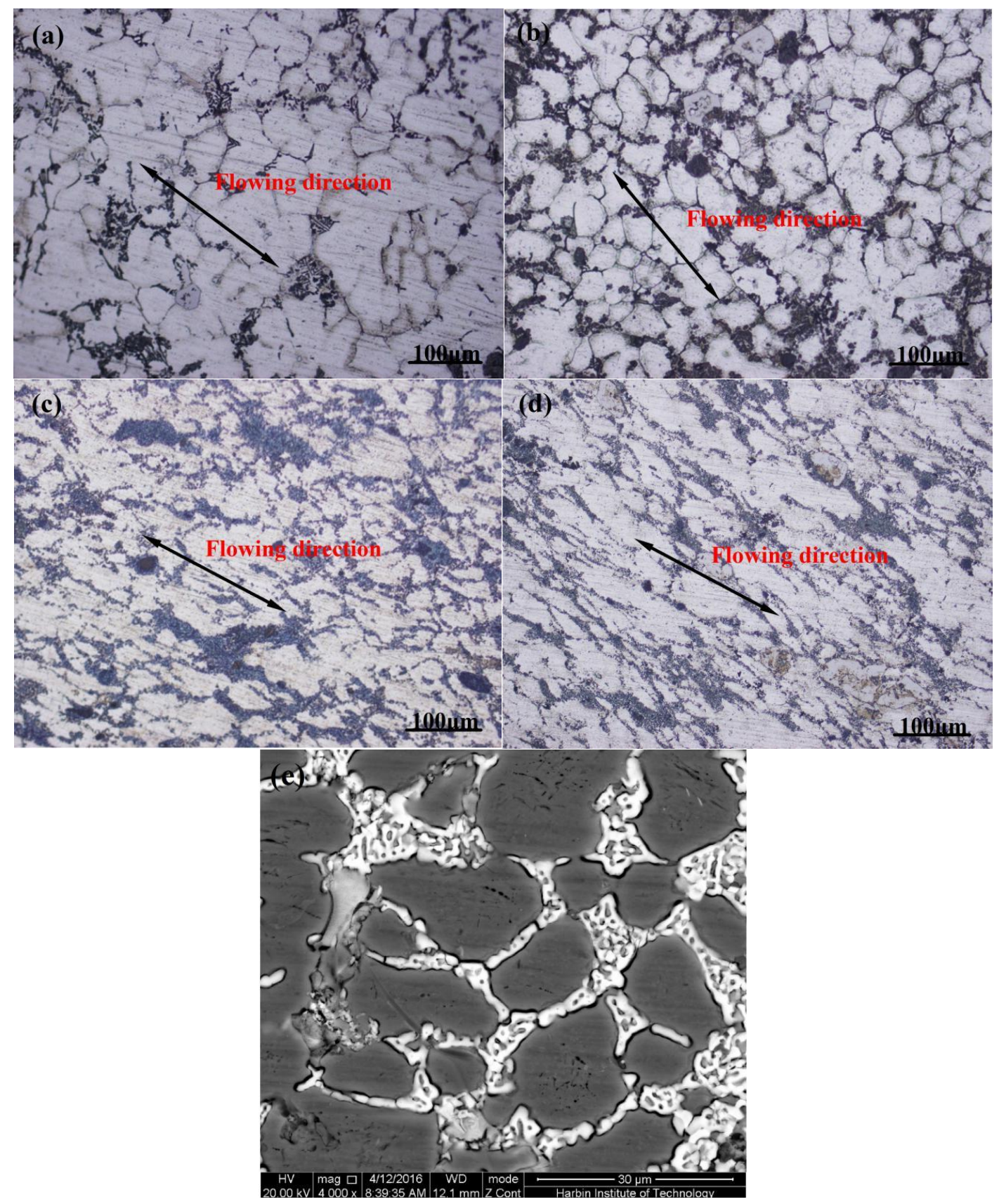

Figure 5. Microstructure of 2024 aluminum matrix composite component reinforced by $5 \mathrm{vol} \% \mathrm{Al}_{2} \mathrm{O}_{3}$ nanoparticles rheoformed at $620^{\circ} \mathrm{C}$ and for $25 \mathrm{~min}$ stirring time. (a) Optical microscope (OM) image in location A of the composite component; (b) OM image in location B of the composite component; (c) OM image in location $\mathrm{C}$ of the composite component; (d) OM image in location D of the composite component; (e) SEM image in location B of the composite component.

It led to near spheroidal solid grains with no obvious plastic deformation. However, the deformation in locations $\mathrm{C}$ and $\mathrm{D}$ was mainly dominated by plastic deformation of solid grains (PDS). Consequently, the elongated solid grains were created along the flowing direction. In addition, it can be noted that the deformation degree in location $\mathrm{D}$ is higher than that in location $\mathrm{C}$ due to low fraction liquid. Figure 5e shows the SEM image of the rheoformed composite component. It illustrates further that the microstructure in location B consisted of near spheroidal grains due to dependence of the deformation on FLS and SSG. 
The microstructure in various locations of the rheoformed original 2024 is similar to that of the composite component (Figure 6). As a consequence, the deformation mechanisms in locations A and B rely on FLS and SSG. The deformation mechanisms in locations C and D depend on PDS. The SEM image in location B of 2024 matrix component is presented in Figure 6e. As shown in Figure 6e, similar to the composite, the microstructure of the rheoformed original 2024 consisted of near spheroidal grains and liquid phase. It illustrates that the deformation mechanism depends on the FLS and SSG. However, the size of the solid grains of the rheoformed composite component is obviously smaller than that of the rheoformed original 2024. It was attributed to the action of nano-sized $\mathrm{Al}_{2} \mathrm{O}_{3}$ particles as heterogeneous nuclei during the solidification of aluminum alloy [24].

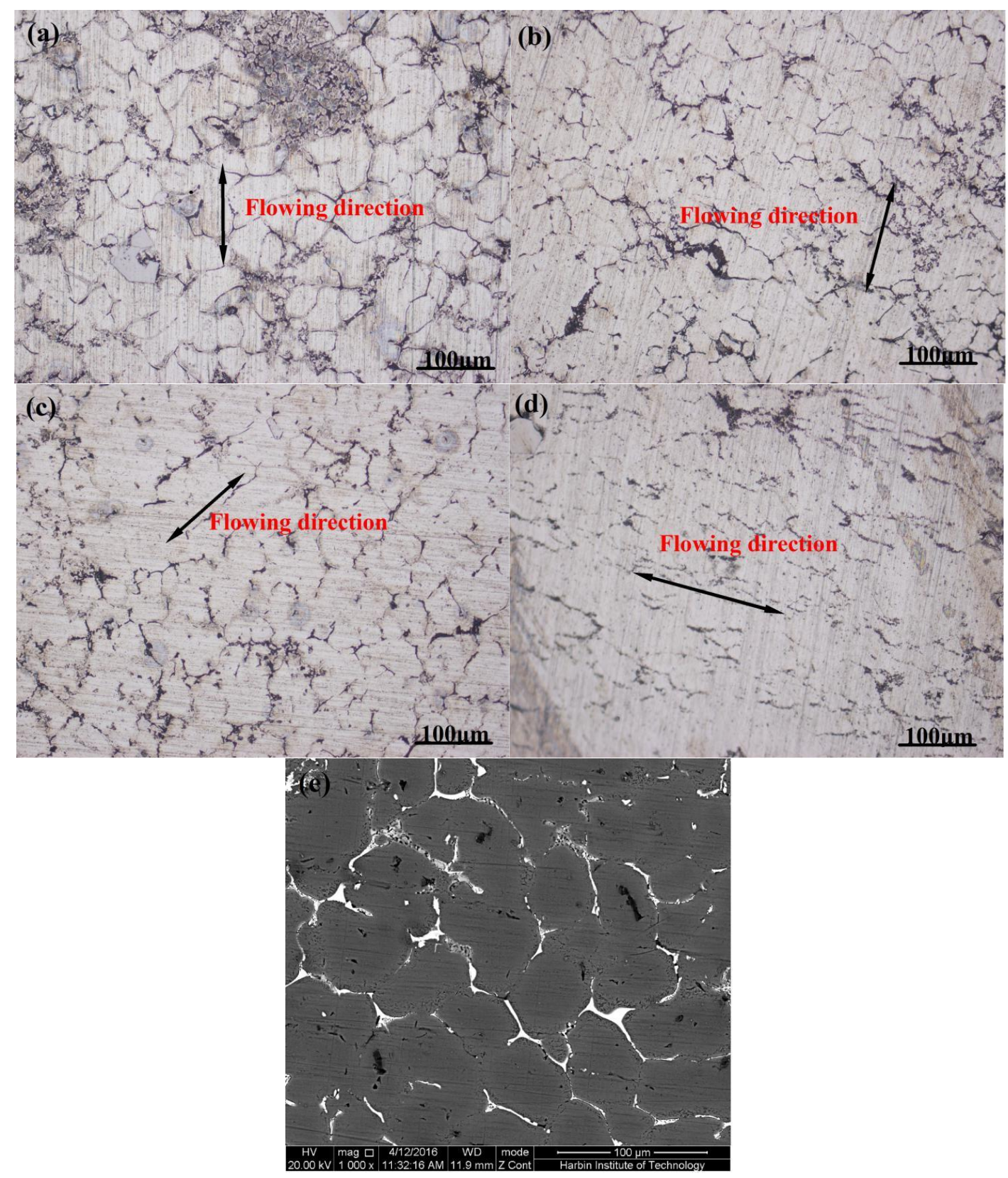

Figure 6. Microstructure of the original 2024 rheoformed at $620^{\circ} \mathrm{C}$ and for $25 \mathrm{~min}$ stirring time. (a) $\mathrm{OM}$ image in location A of the matrix component; (b) OM image in location B of the matrix component; (c) OM image in location $\mathrm{C}$ of the matrix component; (d) OM image in location $\mathrm{D}$ of the matrix component; (e) SEM image in location B of 2024 matrix component. 


\subsection{Influence of Stirring Temperature and Stirring Time on Mechanical Properties}

Figure 7 shows mechanical properties of the rheoformed composite components reinforced by $5 \mathrm{vol} \% \mathrm{Al}_{2} \mathrm{O}_{3}$ nanoparticles and matrix components for $25 \mathrm{~min}$ stirring time at different stirring temperatures. As indicated in Figure 7, ultimate tensile strength (UTS), yield strength (YS), and elongation all increase and then decrease with an elevated stirring temperature. The highest UTS of $315 \mathrm{MPa}$ in the side wall and the highest UTS of $358 \mathrm{MPa}$ at the bottom were obtained at $620^{\circ} \mathrm{C}$. The highest YS of $238 \mathrm{MPa}$ in the side wall and the highest YS of $245 \mathrm{MPa}$ at the bottom were obtained at $620{ }^{\circ} \mathrm{C}$. The highest elongation of $5.3 \%$ in the side wall and the highest elongation of $5.6 \%$ at the bottom were all obtained at $620^{\circ} \mathrm{C}$. Similar to the composite components, the optimal mechanical properties were also obtained at $620^{\circ} \mathrm{C}$. It illustrated that $620^{\circ} \mathrm{C}$ was the optimal stirring temperature to obtain the highest mechanical properties. In addition, UTS and elongation at the bottom were higher than the side wall. It is due to the fact that severe plastic deformation occurred in the bottom location of the rheoformed composite components (Figure 4d). The UTS and YS of the matrix components are lower than those of the composite components. The YS in the side wall of the composite and matrix components was close to that at the bottom.
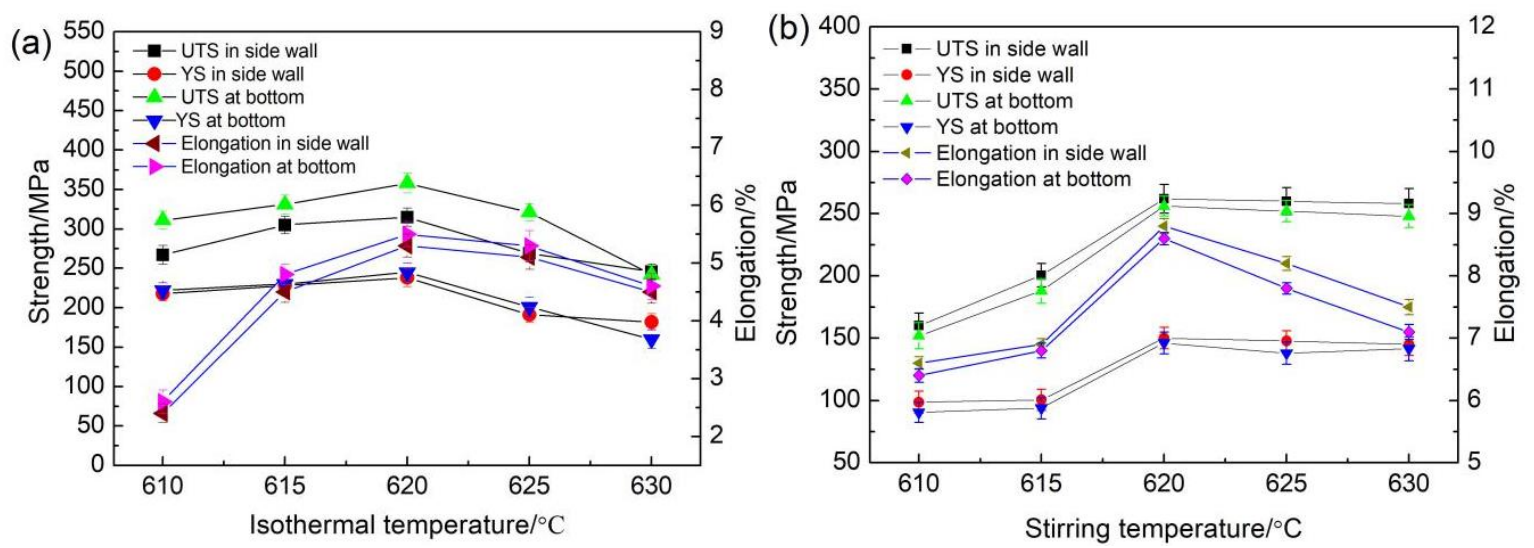

Figure 7. Influence of different stirring temperature on mechanical properties of rheoformed composite components reinforced by $5 \mathrm{vol} \% \mathrm{Al}_{2} \mathrm{O}_{3}$ nanoparticles for 25 min stirring time and matrix components (a) composite components; (b) matrix components.

Microstructure evolution with elevating stirring temperature was given in Figure 8 . The microstructure specimens were cut from location B as shown in Figure $4 \mathrm{~b}$. The microstructure consisted of near spheroidal solid grains and liquid phase due to dependence of deformation mechanism on FLS and SSG. Low stirring temperature leads to coarse spheroidal grains. Even some obvious dendrites were found in the microstructure of the rheoformed composite parts. It has an adverse influence on the mechanical properties of the rheoformed composite parts. With the increase in stirring temperature, the grain size of spheroidal grains decreased. The average grain sizes obtained from image analysis are $57 \mu \mathrm{m}, 76 \mu \mathrm{m}, 47 \mu \mathrm{m}, 55 \mu \mathrm{m}$, and $54 \mu \mathrm{m}$ respectively when the stirring temperatures are $610{ }^{\circ} \mathrm{C}$, $615^{\circ} \mathrm{C}, 620^{\circ} \mathrm{C}, 625^{\circ} \mathrm{C}$, and $630^{\circ} \mathrm{C}$.

Therefore, the average size of solid grains in the microstructure at $620^{\circ} \mathrm{C}$ is obviously smaller than those at other stirring temperatures. According to the Hall-Petch effect [31], fine grains can lead to an increase in YS and UTS. Furthermore, stirring temperatures higher than $625{ }^{\circ} \mathrm{C}$ lead to aggregation of liquid phase, which is detrimental to mechanical properties. When stirring temperature is higher than $625^{\circ} \mathrm{C}$, more aggregation of liquid phase also reduced controllable viscosity of semisolid slurries due to the lack of solid grains. The dispersion effect of $\mathrm{Al}_{2} \mathrm{O}_{3}$ nanoparticles was reduced due to decreased viscosity of semisolid slurries. As a result, greater agglomeration of $\mathrm{Al}_{2} \mathrm{O}_{3}$ nanoparticles occurred in the microstructure, leading to a decrease in mechanical properties of the rheoformed composite components. 

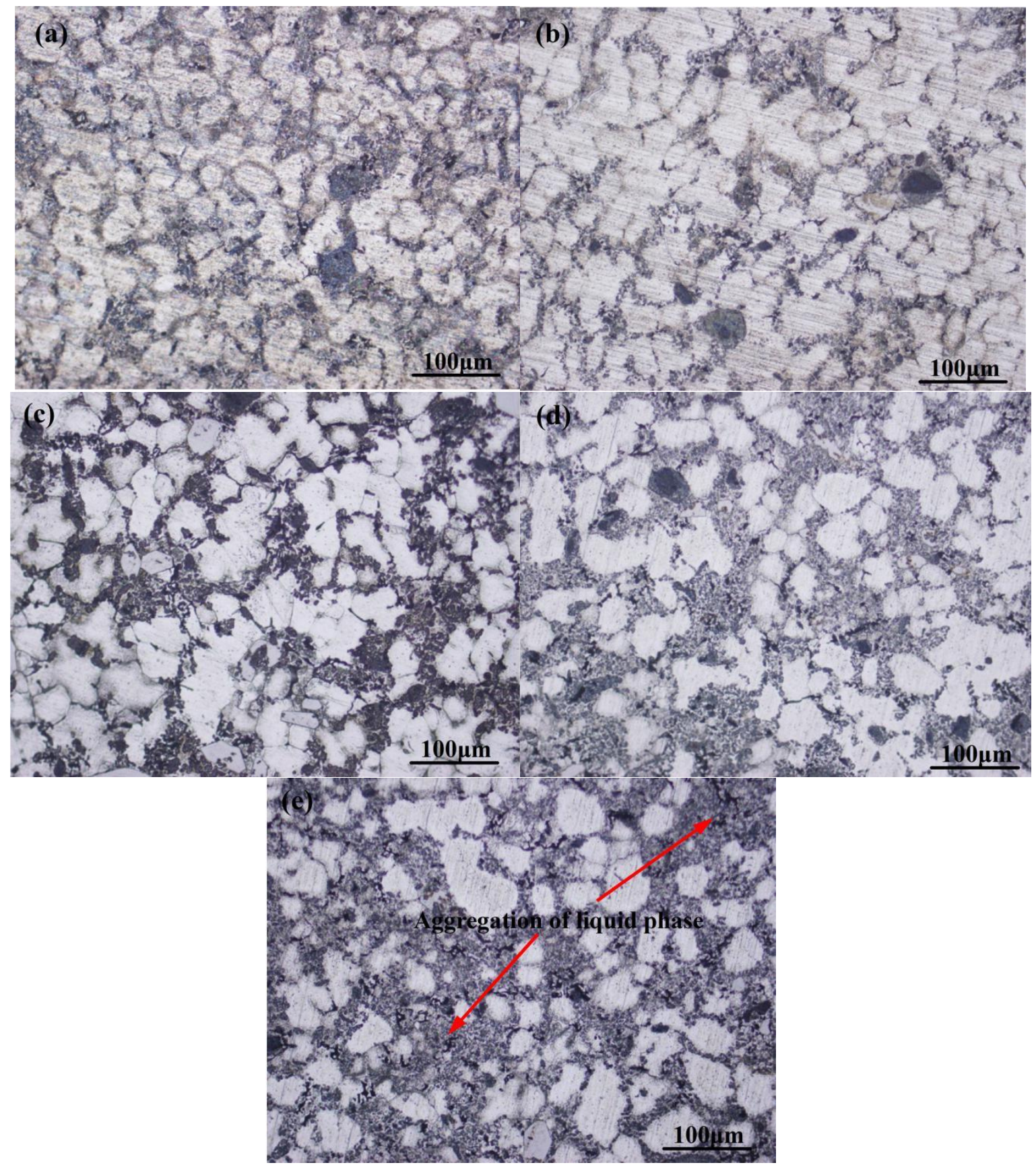

Figure 8. OM microstructure in location B of rheoformed 2024 aluminum matrix composite component reinforced by $5 \mathrm{vol} \% \mathrm{Al}_{2} \mathrm{O}_{3}$ nanoparticles for $25 \mathrm{~min}$ stirring time at various stirring temperatures (a) $610{ }^{\circ} \mathrm{C}$; (b) $615{ }^{\circ} \mathrm{C}$; (c) $620^{\circ} \mathrm{C}$; (d) $625^{\circ} \mathrm{C}$; (e) $630{ }^{\circ} \mathrm{C}$.

Figure 9 shows mechanical properties of the rheoformed composite component reinforced by $5 \mathrm{vol} \% \mathrm{Al}_{2} \mathrm{O}_{3}$ nanoparticles at $620^{\circ} \mathrm{C}$ for different stirring times. As shown in Figure 7 , mechanical properties of rheoformed composite components increased significantly when stirring time increased from $5 \mathrm{~min}$ to $25 \mathrm{~min}$. Mechanical properties of the rheoformed composite component changed slightly when stirring time increased from $25 \mathrm{~min}$ to $30 \mathrm{~min}$. Similar results were found in the rheoformed cylindrical part of the 7075 aluminum matrix composite reinforced with nano-sized SiC particles [28]. The highest mechanical properties including UTS of $358 \mathrm{MPa}$, YS of $245 \mathrm{MPa}$, and elongation of $5.6 \%$ 
were achieved at bottom of the rheoformed cylindrical part of the composite reinforced with $\mathrm{Al}_{2} \mathrm{O}_{3}$ nanoparticles for $25 \mathrm{~min}$ stirring time at $620^{\circ} \mathrm{C}$.

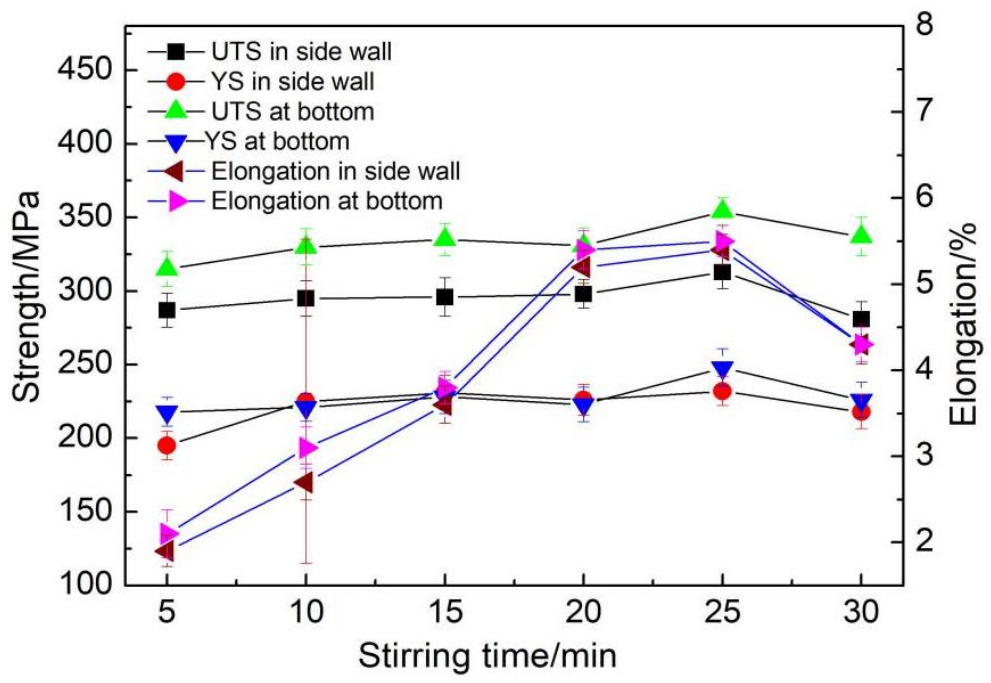

Figure 9. Influence of different stirring time on mechanical properties of rheoformed 2024 aluminum matrix composite component reinforced by $5 \mathrm{vol} \% \mathrm{Al}_{2} \mathrm{O}_{3}$ nanoparticles at $620^{\circ} \mathrm{C}$.

Increasing stirring time resulted in a fine-grained microstructure of composite semisolid slurries (Figure 10). As indicated in Figure 10a, coarse solid grains of more than $200 \mu \mathrm{m}$ were found in the microstructure when stirring time was $5 \mathrm{~min}$. With an increase in stirring time, solid grains were refined significantly (Figure 10b-e). When stirring time was $25 \mathrm{~min}$, the average size of solid grains was about $46 \mu \mathrm{m}$. Fine-grained microstructure can improve mechanical properties of the rheoformed composite components due to the Hall-Petch effect [32]. However, the grain size of solid grains changed slightly when stirring time increased from $25 \mathrm{~min}$ to $30 \mathrm{~min}$. As a result, the mechanical properties of the rheoformed composite components also changed slightly, or even showed a slight decrease.

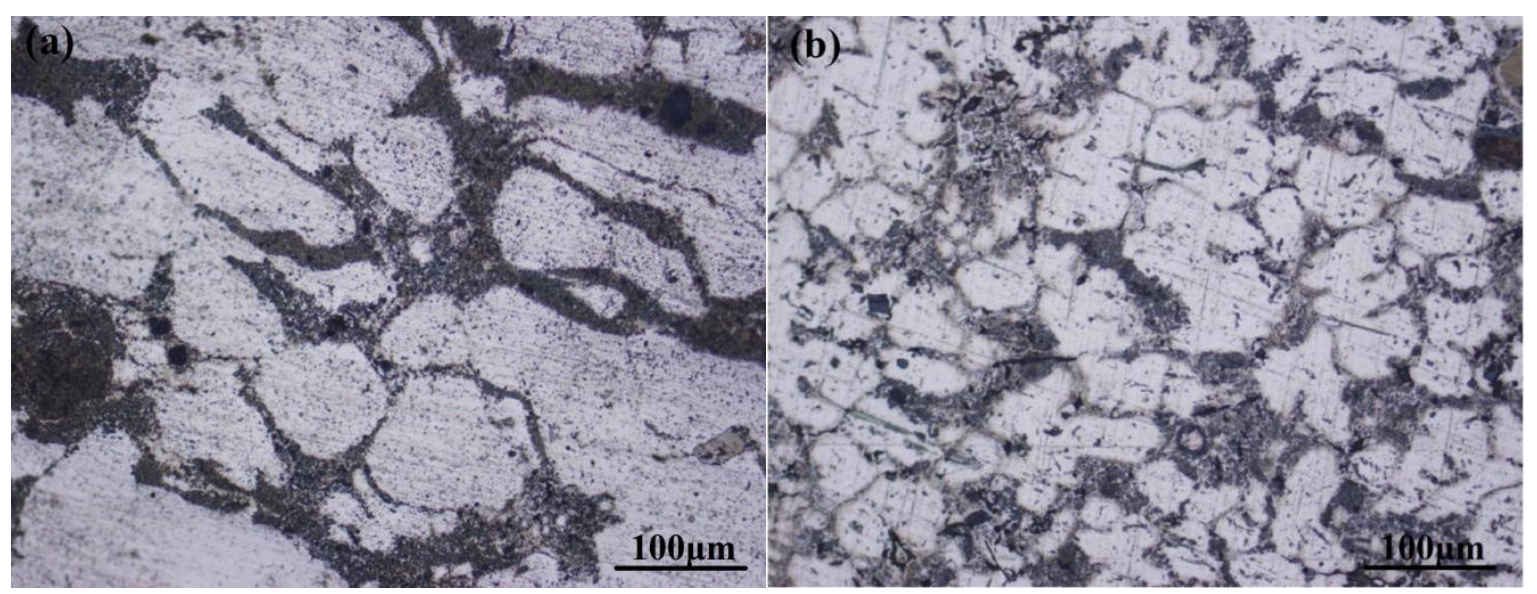

Figure 10. Cont. 


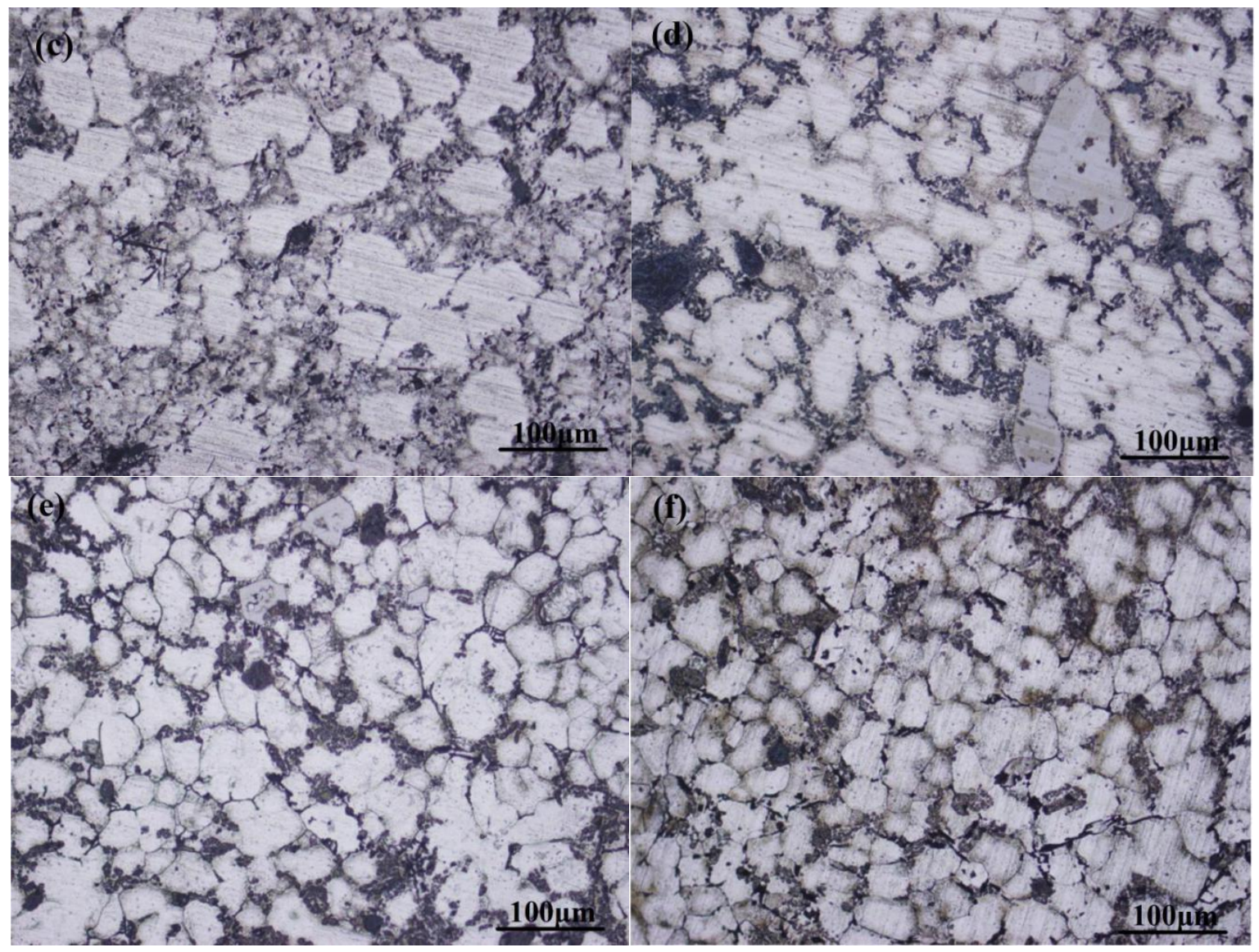

Figure 10. Influence of different stirring time on $\mathrm{OM}$ microstructure in location $\mathrm{B}$ of the rheoformed 2024 aluminum matrix composite component reinforced by $5 \mathrm{vol} \% \mathrm{Al}_{2} \mathrm{O}_{3}$ nanoparticles at $620{ }^{\circ} \mathrm{C}$ (a) $5 \mathrm{~min}$; (b) $10 \mathrm{~min}$; (c) $15 \mathrm{~min}$; (d) $20 \mathrm{~min}$; (e) $25 \mathrm{~min}$; (f) $30 \mathrm{~min}$.

\subsection{Influence of Volume Fraction of $\mathrm{Al}_{2} \mathrm{O}_{3}$ Nanoparticles on Mechanical Properties}

Figure 11 shows the influence of volume fraction of $\mathrm{Al}_{2} \mathrm{O}_{3}$ nanoparticles on mechanical properties of the rheoformed composite components. As indicated in Figure 11, UTS and YS of the rheoformed composite components increased when the volume fraction of $\mathrm{Al}_{2} \mathrm{O}_{3}$ nanoparticles increased from 0 to $5 \%$. UTS values in the side wall and at the bottom of the matrix components are $268 \mathrm{MPa}$ and $272 \mathrm{MPa}$ respectively. When the volume fraction of $\mathrm{Al}_{2} \mathrm{O}_{3}$ nanoparticles increased to $5 \%$, they reached $315 \mathrm{MPa}$ and $358 \mathrm{MPa}$ respectively. The increasing degrees of UTS and $\mathrm{YS}$ are $17.5 \%$ and $31.7 \%$ respectively. $\mathrm{Al}_{2} \mathrm{O}_{3}$ nanoparticles act as barriers of dislocations mobility, leading to an improvement of UTS and YS [33]. In addition, mismatch of coefficient of thermal expansion (CTE) between the matrix and reinforcement phase, load transfer from matrix to reinforcement phase and Orowan strengthening mechanism also play an important role in improving the mechanical properties [34-36]. $\mathrm{Al}_{2} \mathrm{O}_{3}$ nanoparticles also acted as heterogeneous nuclei for the aluminum alloy matrix, leading to a grain-refined strengthening effect $[24,37,38]$. The improvement of mechanical properties may be related to the residual stress and fracture toughness at the interface between the $\mathrm{Al}_{2} \mathrm{O}_{3}$ and the $\mathrm{Al}$ matrix. However, it is very difficult to measure the residual stress and fracture toughness at the interface between the $\mathrm{Al}_{2} \mathrm{O}_{3}$ and the $\mathrm{Al}$ matrix, and it could be helpful to employ nanoindentation and pillar splitting techniques as reported by Matteo Ghidelli et al. [39,40]. 


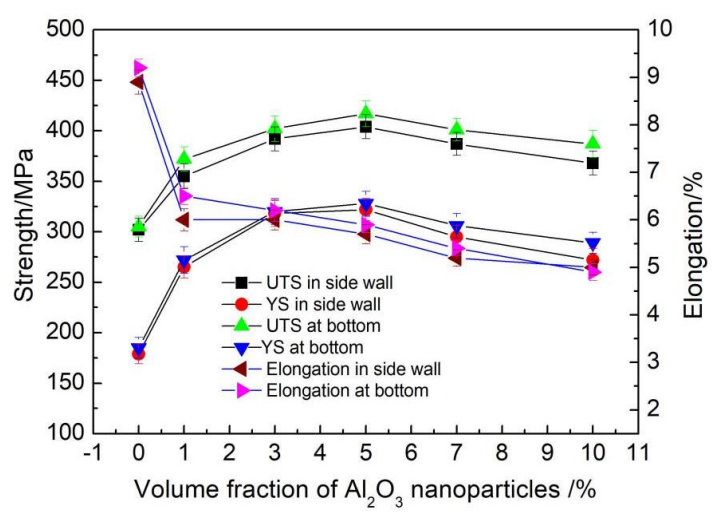

Figure 11. Influence of volume fraction of nano-sized $\mathrm{Al}_{2} \mathrm{O}_{3}$ on mechanical properties of rheoformed 2024 aluminum matrix composite component reinforced by 5 vol $\% \mathrm{Al}_{2} \mathrm{O}_{3}$ nanoparticles at $620{ }^{\circ} \mathrm{C}$ for 25 min stirring time.

In addition, it can be noted that UTS and YS of the rheoformed composite components decreased slightly when the volume fraction of $\mathrm{Al}_{2} \mathrm{O}_{3}$ nanoparticles was more than $5 \%$. It was attributed to greater agglomeration of $\mathrm{Al}_{2} \mathrm{O}_{3}$ nanoparticles that occurred in the composite due to a large volume fraction of $\mathrm{Al}_{2} \mathrm{O}_{3}$ nanoparticles [37]. A similar phenomenon was found in the research of Mazahery et al. [41] and Su et al. [37]. Mechanical properties in the present study were higher than those of Su et al. [37]. It may be due to the effect of a different fabrication method and different component shape on mechanical properties. Elongation of the rheoformed composite components is lower than that of the matrix component. In addition, elongation of the rheoformed composite components decreased with increasing volume fraction of $\mathrm{Al}_{2} \mathrm{O}_{3}$ nanoparticles. UTS at the bottom of the rheoformed composite components was higher as compared to that of the side wall. Figure 12 depicts the microstructure of rheoformed composite reinforced by nano-sized $\mathrm{Al}_{2} \mathrm{O}_{3}$ particles and matrix components at $620^{\circ} \mathrm{C}$ and for 25 min stirring time.

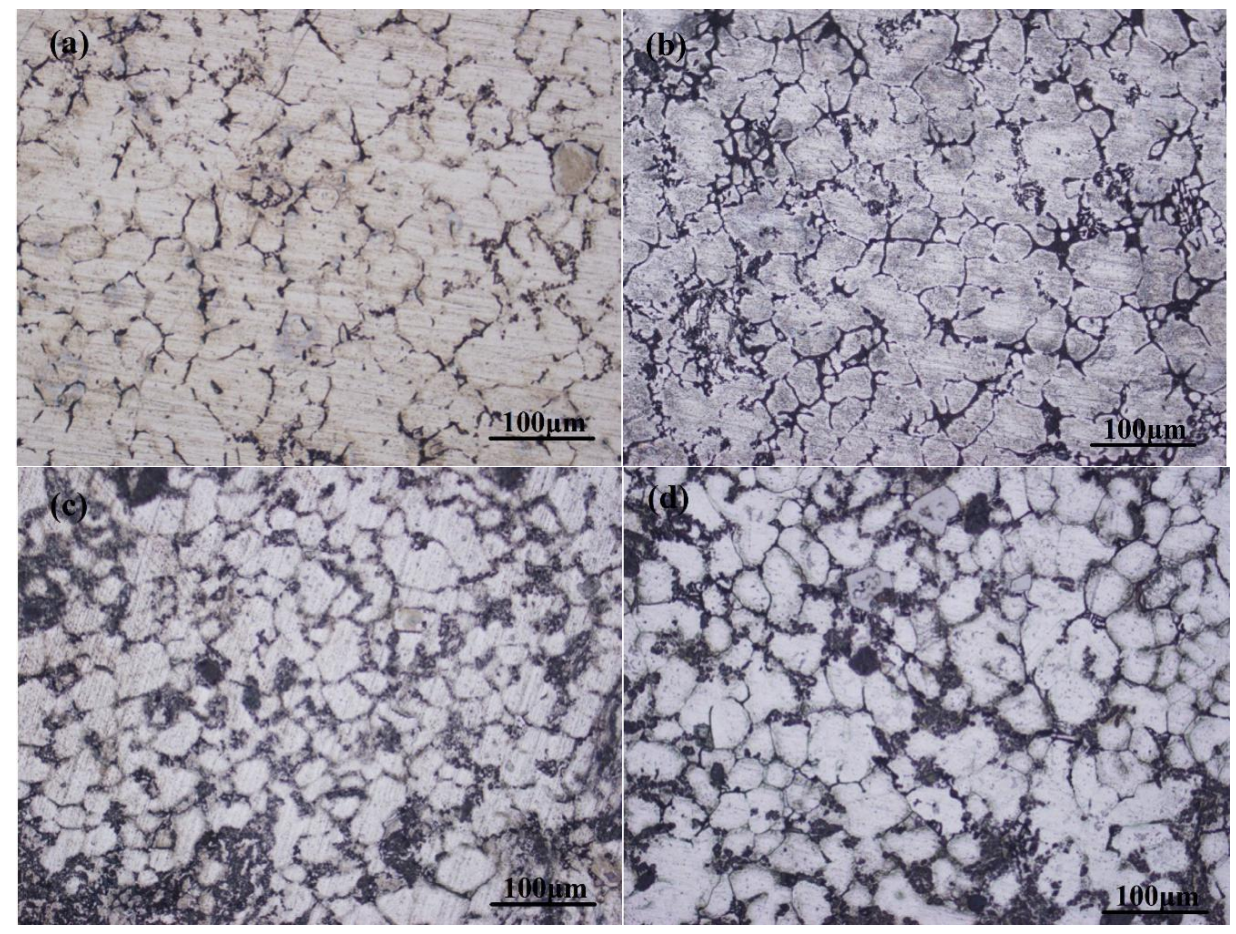

Figure 12. Cont. 


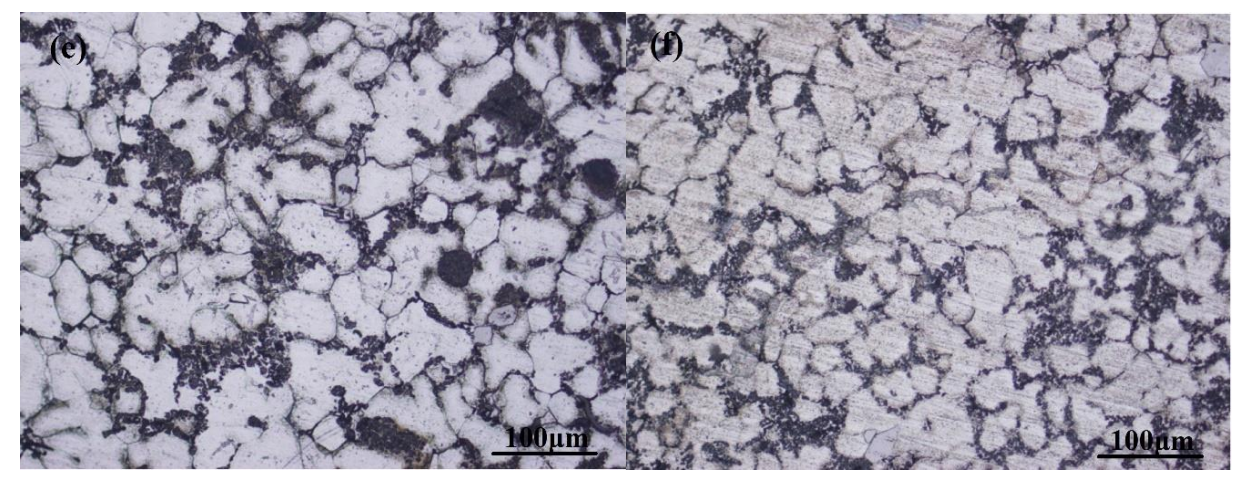

Figure 12. OM microstructure of rheoformed 2024 aluminum matrix composite component reinforced by different volume fraction of $\mathrm{Al}_{2} \mathrm{O}_{3}$ nanoparticles at $620{ }^{\circ} \mathrm{C}$ and for $25 \mathrm{~min}$ stirring time (a) 2024 matrix; (b) $1 \%$; (c) $3 \%$; (d) $5 \%$; (e) $7 \%$; (f) $10 \%$.

Average grain size of the rheoformed composite components was smaller than that of the matrix component. It is due to the increasing heterogeneous nucleation for the aluminum matrix created by $\mathrm{Al}_{2} \mathrm{O}_{3}$ nanoparticles [37,38]. It is helpful to improve the UTS and YS of the rheoformed composite components due to a grain-refined strengthening effect $[24,37,38]$.

\subsection{Microstructure Characterization of the Rheoformed Composite Components}

Figure 13 shows TEM micrographs at bottom of the rheoformed composite component reinforced by $5 \mathrm{vol} \% \mathrm{Al}_{2} \mathrm{O}_{3}$ nanoparticles. As shown in Figure 13a-e, $\mathrm{Al}_{2} \mathrm{O}_{3}$ nanoparticles distributed uniformly in the matrix alloy. It is due to the fact that cavitation and acoustic streaming created via ultrasonic wave dispersed $\mathrm{Al}_{2} \mathrm{O}_{3}$ nanoparticles uniformly [26,42]. In addition, further dispersion of $\mathrm{Al}_{2} \mathrm{O}_{3}$ nanoparticles was obtained via controllable viscosity of semisolid slurries [27-29]. However, few $\mathrm{Al}_{2} \mathrm{O}_{3}$ nanoparticles were found in the TEM microstructure at a stirring temperature of $630^{\circ} \mathrm{C}$ (Figure 13f). It may be due to the fact that greater agglomeration of $\mathrm{Al}_{2} \mathrm{O}_{3}$ nanoparticles leads to nonuniform dispersion of $\mathrm{Al}_{2} \mathrm{O}_{3}$ nanoparticles. This result also provided good evidence for the decreased mechanical properties of the rheoformed composite components at $630{ }^{\circ} \mathrm{C}$ (Figure 7a).

High density dislocations and dislocation tangles were found in the TEM images. Deformation of composite semisolid slurries depends on flow of liquid incorporating solid grains (FLS), sliding between solid grains (SSG), and plastic deformation of solid grains (PDS). PDS dominated the deformation of the semisolid slurry at the bottom. Therefore, plastic deformation at the bottom mainly relied on dislocation mobility. As a result, some dislocations were created due to plastic deformation, as shown in Figure 13. Twin crystal was noticed in the TEM microstructure (Figure 13b). It indicated that twinning also occurred in the plastic deformation of solid grains of semisolid slurries. Furthermore, some sub-grains were found in the twin crystal. It is due to the fact that dynamic recovery occurred in rheoformed composite components during the cooling course. Furthermore, $\mathrm{Al}_{2} \mathrm{O}_{3}$ nanoparticles were surrounded by these high density dislocations (Figure 13a,c,d).

$\mathrm{Al}_{2} \mathrm{O}_{3}$ nanoparticles acted as barriers of dislocations, leading to an enhancement of the mechanical properties of the rheoformed composite components [33]. It demonstrates that two strengthening mechanisms including dislocation strengthening caused by PDS and interaction between $\mathrm{Al}_{2} \mathrm{O}_{3}$ nanoparticles and dislocations play an important role in improving the mechanical properties of the rheoformed composite components together.

EDX analysis of $\mathrm{Al}_{2} \mathrm{O}_{3}$ nanoparticles on microstructure of rheoformed composite components reinforced was shown in Figure 14. $\mathrm{Al}_{2} \mathrm{O}_{3}$ nanoparticles, $\mathrm{Al}_{2} \mathrm{Cu}$ phase, and $\mathrm{MgAl}_{2} \mathrm{O}_{4}$ phase were determined via mapping of $\mathrm{Al}, \mathrm{Cu}, \mathrm{Mg}$, and $\mathrm{O}$ elements. 


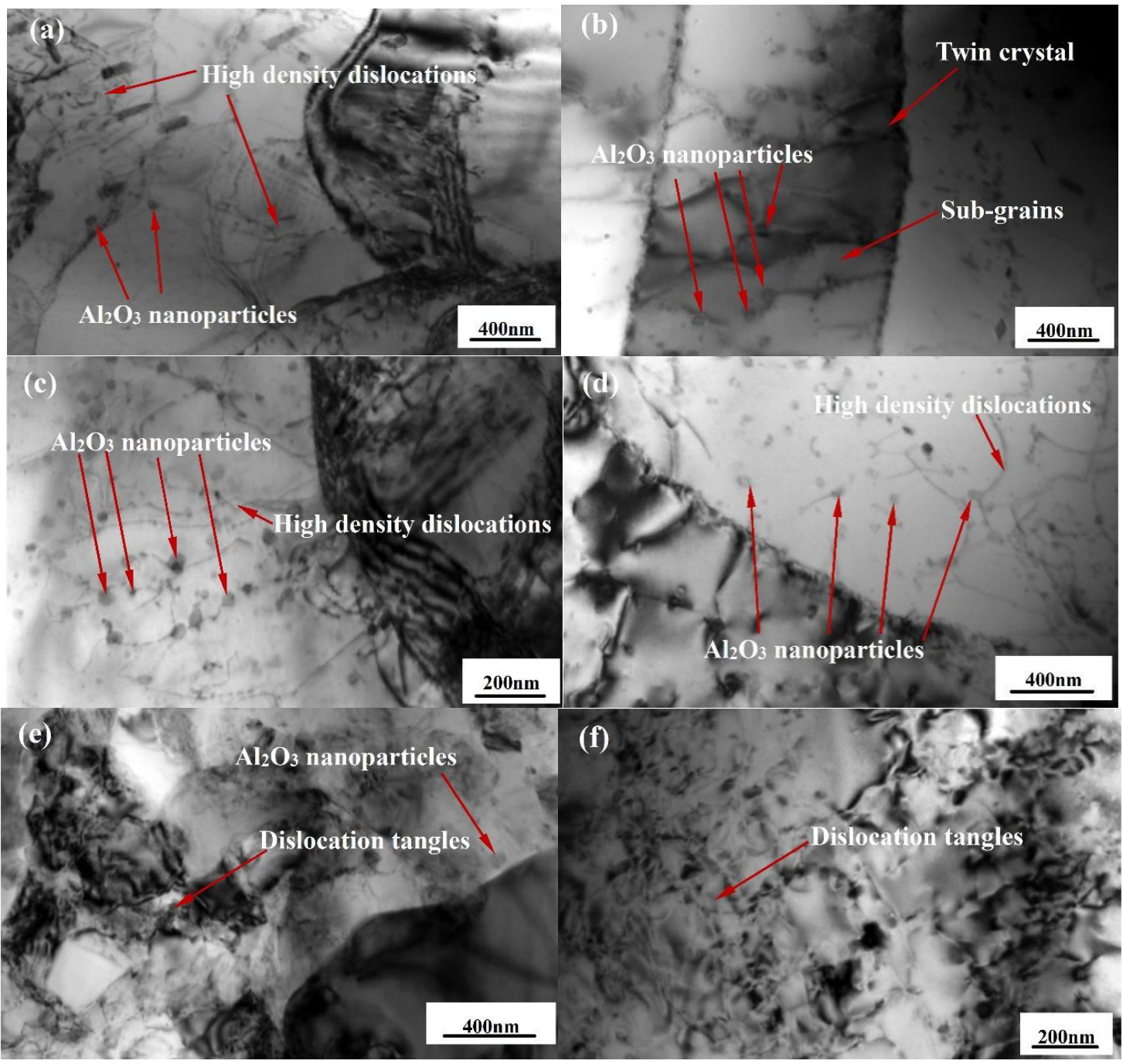

Figure 13. TEM micrographs of rheoformed composite component reinforced by 5 vol $\% \mathrm{Al}_{2} \mathrm{O}_{3}$ nanoparticles at $(\mathbf{a}, \mathbf{b}) 610^{\circ} \mathrm{C}$; (c,d) $620^{\circ} \mathrm{C}$ and $(\mathbf{e}, \mathbf{f}) 630^{\circ} \mathrm{C}$.

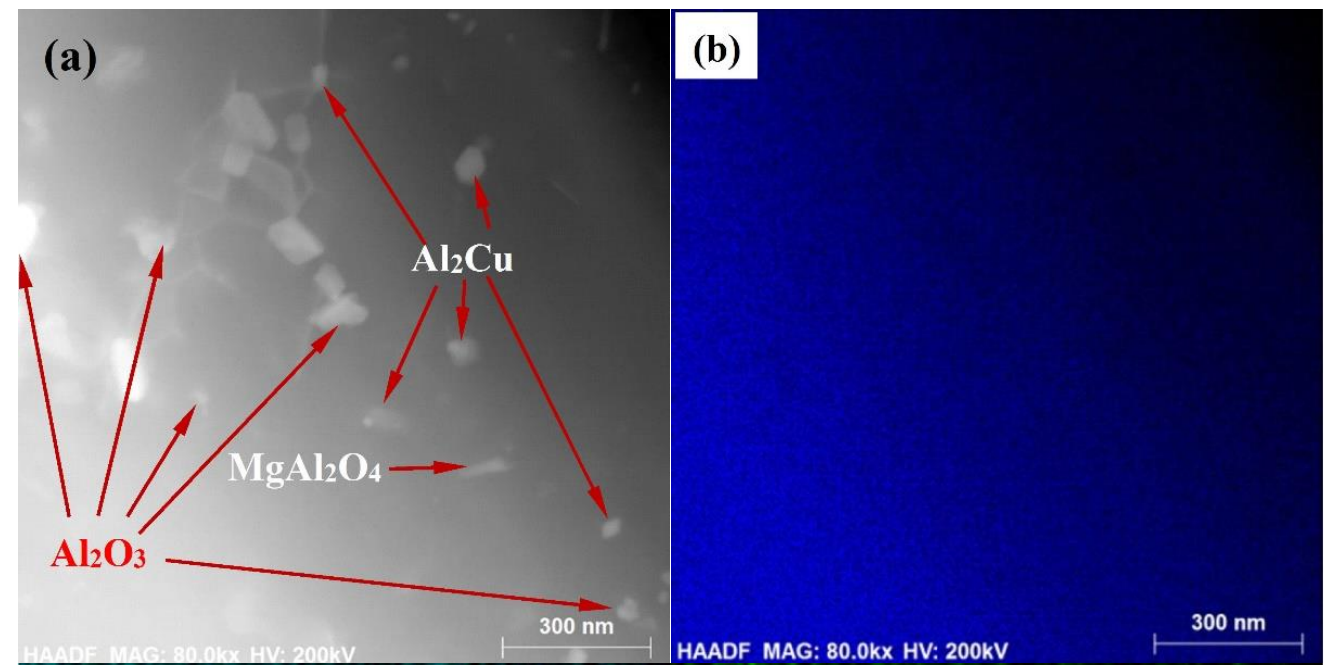

Figure 14. Cont. 


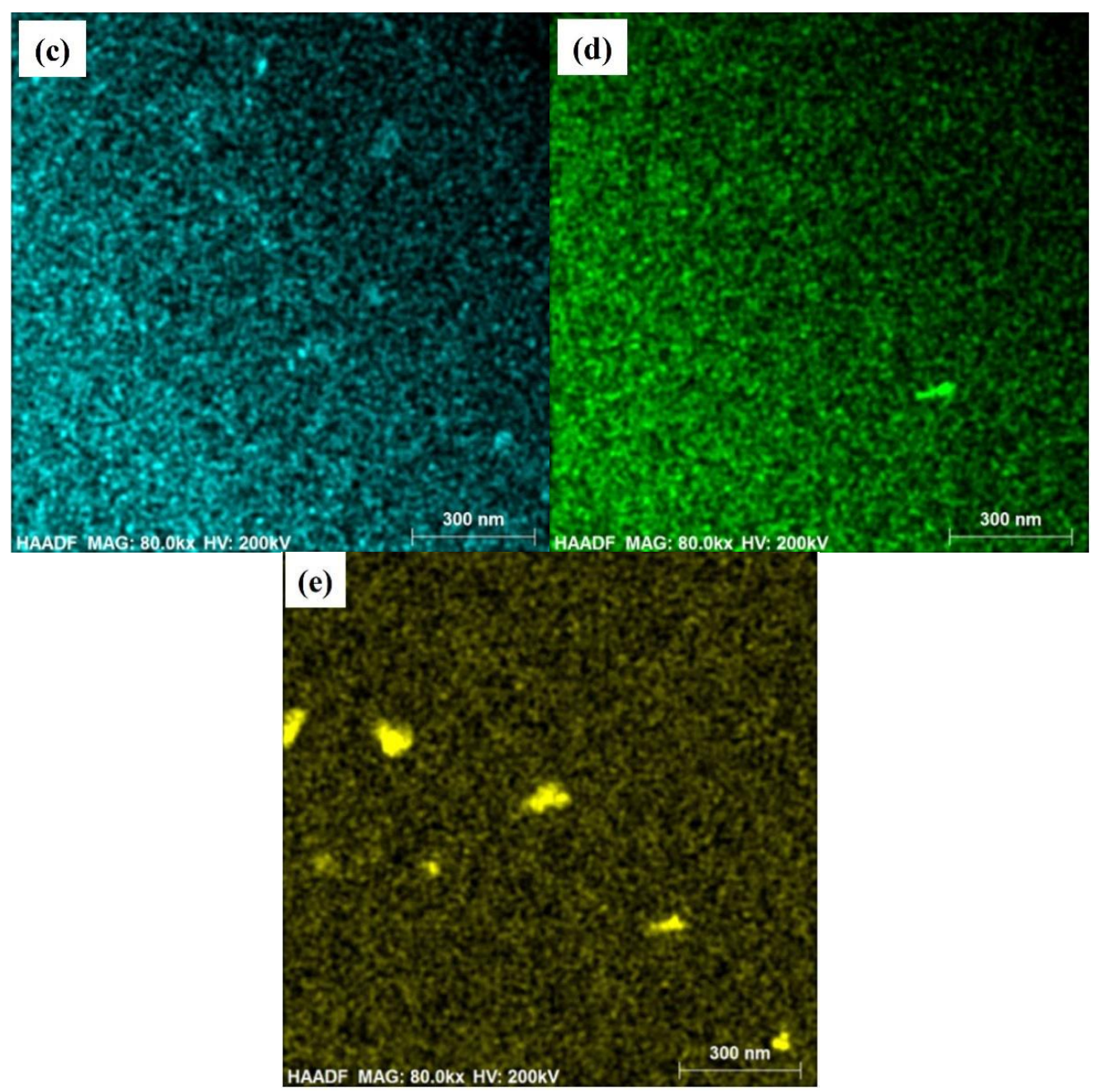

Figure 14. Energy dispersive $\mathrm{X}$-ray spectrometer (EDX) analysis of nano-sized $\mathrm{Al}_{2} \mathrm{O}_{3}$ on microstructure of rheoformed 2024 aluminum matrix composite component reinforced by $5 \mathrm{vol} \% \mathrm{Al}_{2} \mathrm{O}_{3}$ nanoparticles at $615{ }^{\circ} \mathrm{C}$ for for 25 min stirring time (a) TEM micrograph; (b) $\mathrm{Al}$; (c) $\mathrm{Cu}$; (d) $\mathrm{Mg}$; (e) $\mathrm{O}$.

As indicated in Figure 14, uniform dispersion of $\mathrm{Al}_{2} \mathrm{O}_{3}$ nanoparticles was noted in the TEM image due to double dispersion of cavitation and acoustic streaming created by ultrasonic wave and controllable viscosity of semisolid slurries. Existence of $\mathrm{Al}_{2} \mathrm{Cu}$ phase was due to natural ageing that occurred at room temperature. $\mathrm{MgAl}_{2} \mathrm{O}_{4}$ phase illustrates that an interface reaction occurred in the interface of $\mathrm{Al}$ and $\mathrm{Al}_{2} \mathrm{O}_{3}$ nanoparticles due to existence of $\mathrm{Mg}$ element. $\mathrm{MgAl}_{2} \mathrm{O}_{4}$ phase has some advantages such as low density, high melting point, good wear resistance, good heat stability, and high mechanical properties [43,44]. Furthermore, relatively good wetting was obtained at the interface $\mathrm{Al}, \mathrm{MgAl}_{2} \mathrm{O}_{4}$, and $\mathrm{Al}_{2} \mathrm{O}_{3}$ [45]. Therefore, the existence of $\mathrm{MgAl}_{2} \mathrm{O}_{4}$ phase has no effect on mechanical properties of the rheoformed composite components.

Figure 15 shows TEM microstructure and SAED of rheoformed composite components reinforced by 5 vol \% $\mathrm{Al}_{2} \mathrm{O}_{3}$ nanoparticles for 25 min stirring time at $615{ }^{\circ} \mathrm{C}$ and $625{ }^{\circ} \mathrm{C}$. As indicated in Figure 15, short-rod-like $\mathrm{Al}_{2} \mathrm{Cu}$ phase and needle-like $\mathrm{Al}_{2} \mathrm{CuMg}$ phase were determined via selected area electron diffraction (SAED). The second phases such as $\mathrm{Al}_{2} \mathrm{Cu}$ phase and $\mathrm{Al}_{2} \mathrm{CuMg}$ act as the role of strengthening the 2024 aluminum alloy. After the rheoformed composite components were cooling down to room temperature, these second phases precipitated in the 2024 matrix and strengthened it due to natural ageing that occurred in the components. These second phases also hindered the dislocation movement while the semisolid slurries were deformed. As a result, the mechanical properties of the rheoformed composite component were improved. 


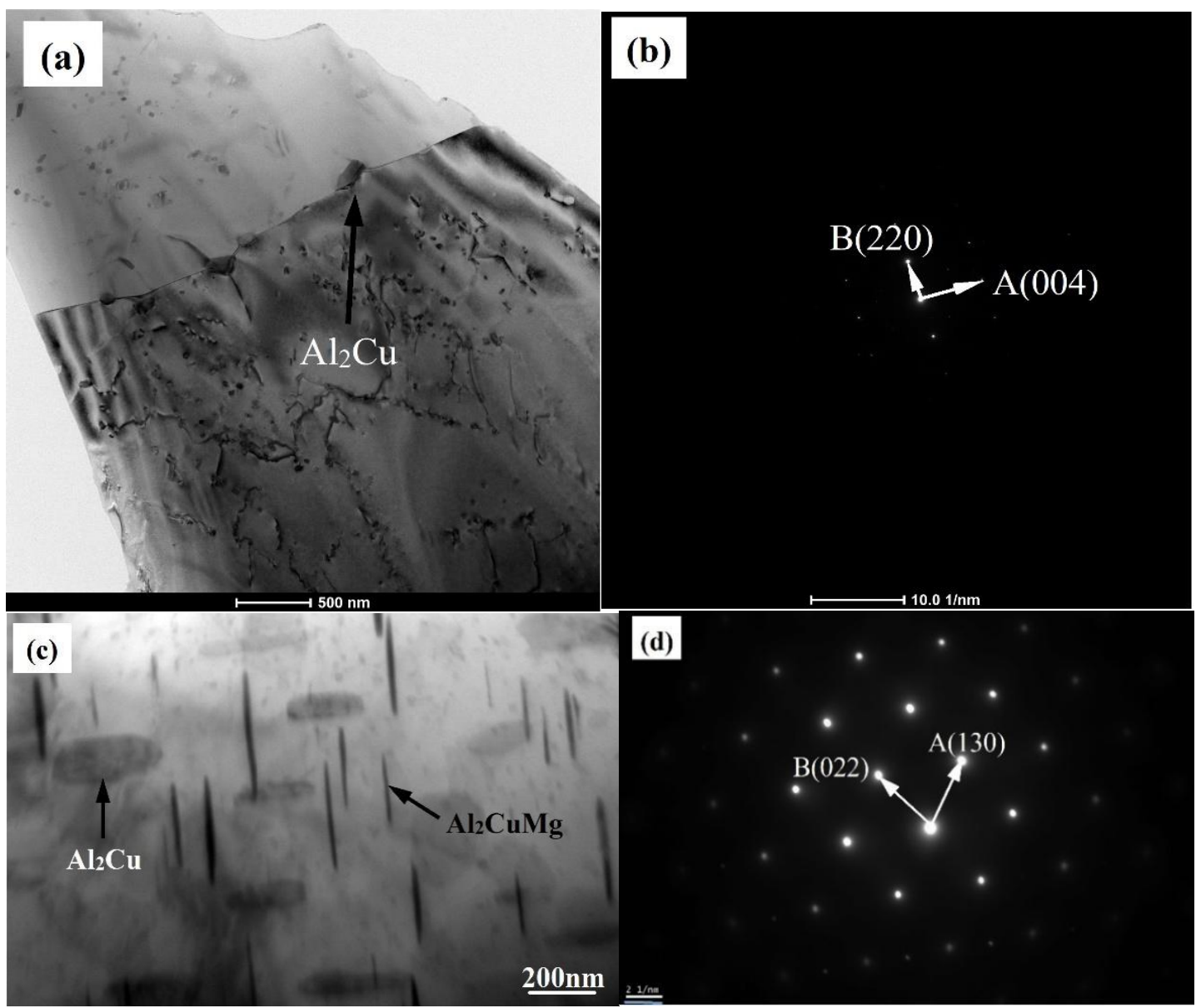

Figure 15. TEM microstructure and selected area electron diffraction (SAED) of rheoformed 2024 aluminum matrix composite component reinforced by $5 \mathrm{vol} \% \mathrm{Al}_{2} \mathrm{O}_{3}$ nanoparticles for 25 min stirring time at $615{ }^{\circ} \mathrm{C}$ and $625{ }^{\circ} \mathrm{C}$ (a) TEM image at $615{ }^{\circ} \mathrm{C}$ (b) SAED at $615{ }^{\circ} \mathrm{C}$ (c) TEM image at $625{ }^{\circ} \mathrm{C}$ (d) SAED at $625^{\circ} \mathrm{C}$.

SEM image and EDX analysis in location B of the rheoformed composite component are presented in Figure 16. As shown in Figure 16a, the microstructure consisted of spheroidal solid grains (grey black color) and liquid phase (white color). It illustrates that the deformation mechanism of semisolid slurry in location B belongs to flow of liquid incorporating solid grains (FLS), sliding between solid grains (SSG). The atom ratio of aluminum and copper at grain boundary is close to 2:1 according to the Figure 16b. It illustrated that the liquid phase at the grain boundary was mainly composed of $\theta$ phase $\left(\mathrm{Al}_{2} \mathrm{Cu}\right)$. The spheroidal solid grains contained a large amount of $\mathrm{Al}$ elements and a small amount of $\mathrm{Cu}$ and $\mathrm{Mg}$ elements, as show in Figure 16c. It illustrates that the spheroidal solid phase is $\alpha$-Al phase. The $\alpha$-Al phase is a solid solution of copper and magnesium in aluminum. Existence of $\mathrm{O}$ element was attributed to oxidation occurred in the grinding course of the specimens.

\subsection{Influence of T6 Heat Treatment on Mechanical Properties}

Mechanical properties of the rheoformed composite components reinforced by $\mathrm{Al}_{2} \mathrm{O}_{3}$ nanoparticles at $620^{\circ} \mathrm{C}$ and for $25 \mathrm{~min}$ stirring time after T6 heat treatment are indicated in Figure 17. As indicated in Figure 17, mechanical properties of the rheoformed composite components were improved significantly after T6 heat treatment. UTS of 417MPa and YS of $328 \mathrm{MPa}$ were achieved at the bottom of the rheoformed composite components at $620{ }^{\circ} \mathrm{C}$. UTS and YS of the composite components with T6 heat treatment were $16.5 \%$ and $20.6 \%$ respectively, higher than those of the composite component without T6 heat treatment. Elongation of the composite components with T6 
heat treatment was increased by $5.6 \%$ as compared to the composite component without T6 heat treatment. UTS and YS of the composite components with T6 heat treatment were increased by $36.7 \%$ and $49.1 \%$ respectively as compared to the matrix component with T6 heat treatment.
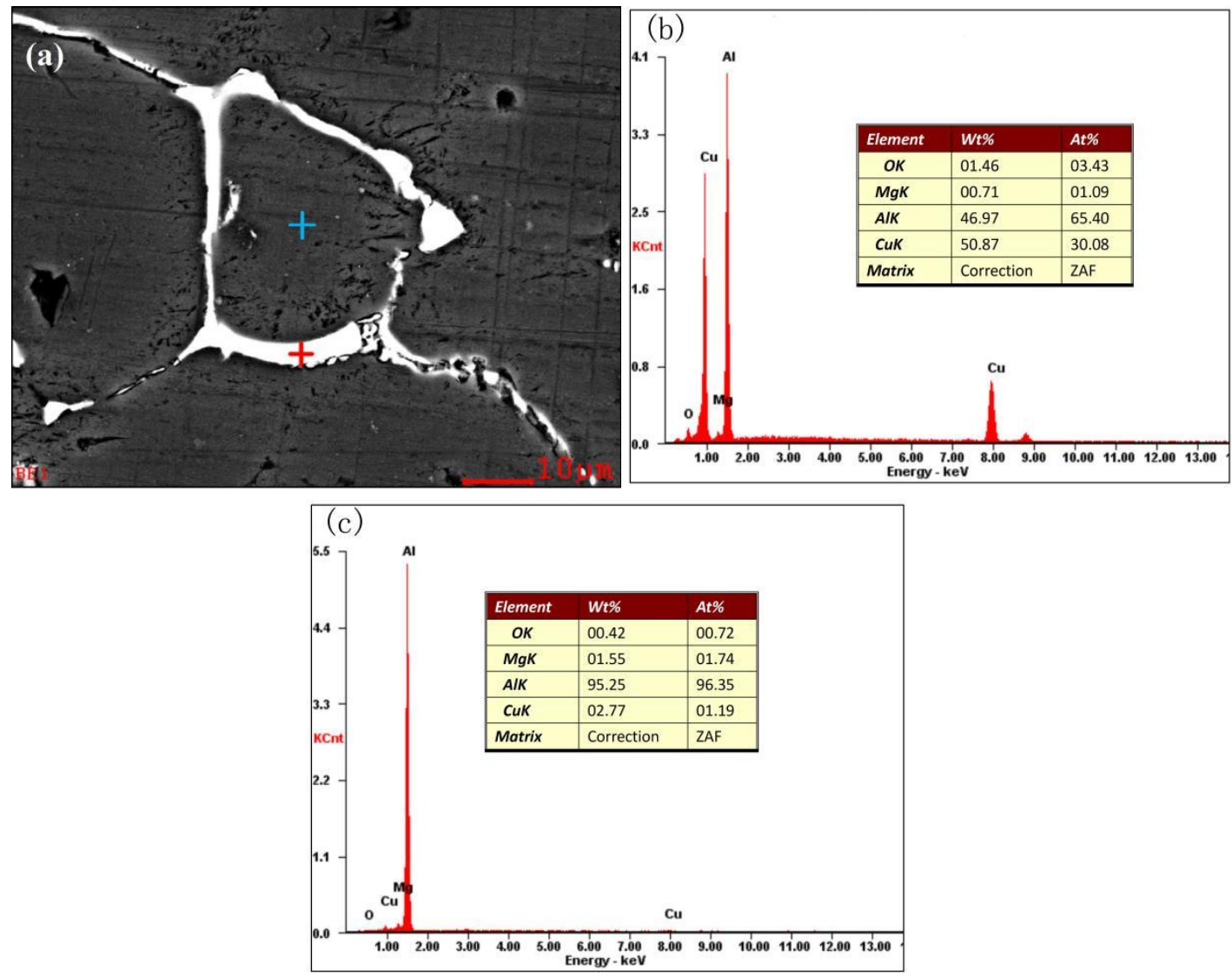

Figure 16. SEM image and EDX analysis of the rheoformed matrix components (a) SEM image; (b) EDX in location marked with red cross; (c) EDX in location marked with blue cross.

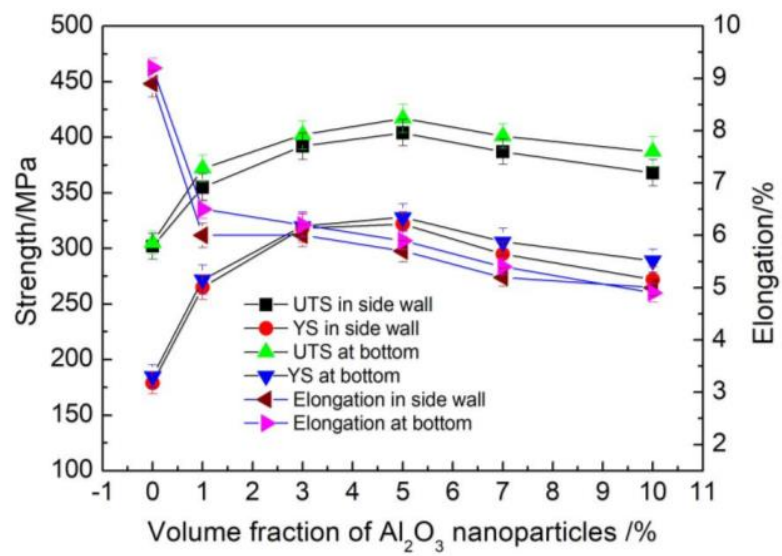

Figure 17. Mechanical properties of rheoformed 2024 aluminum matrix composite component reinforced by $\mathrm{Al}_{2} \mathrm{O}_{3}$ nanoparticles at $620^{\circ} \mathrm{C}$ and for $25 \mathrm{~min}$ stirring time after $\mathrm{T} 6$ heat treatment.

TEM and EDX of the rheoformed composite components reinforced by 5 vol \% $\mathrm{Al}_{2} \mathrm{O}_{3}$ nanoparticles at $620^{\circ} \mathrm{C}$ after T6 heat treatment are shown in Figure 18. Short-rod-like $\mathrm{Al}_{2} \mathrm{Cu}$ phase and needle-like $\mathrm{Al}_{2} \mathrm{CuMg}$ phase were found in the TEM image of the rheoformed composite components. 
The length and width of the short-rod-like $\mathrm{Al}_{2} \mathrm{Cu}$ phase are about $100 \mathrm{~nm}$ and $65 \mathrm{~nm}$ respectively. As for needle-like $\mathrm{Al}_{2} \mathrm{CuMg}$ phase, its length varies from $150 \mathrm{~nm}$ to $200 \mathrm{~nm}$. Its width is in a range from $20 \mathrm{~nm}$ to $50 \mathrm{~nm}$. The mechanical properties of the rheoformed composite component after T6 treatment were improved because of the needle-like $\mathrm{Al}_{2} \mathrm{CuMg}$ phase and the short-rod-like $\mathrm{Al}_{2} \mathrm{Cu}$ phase.
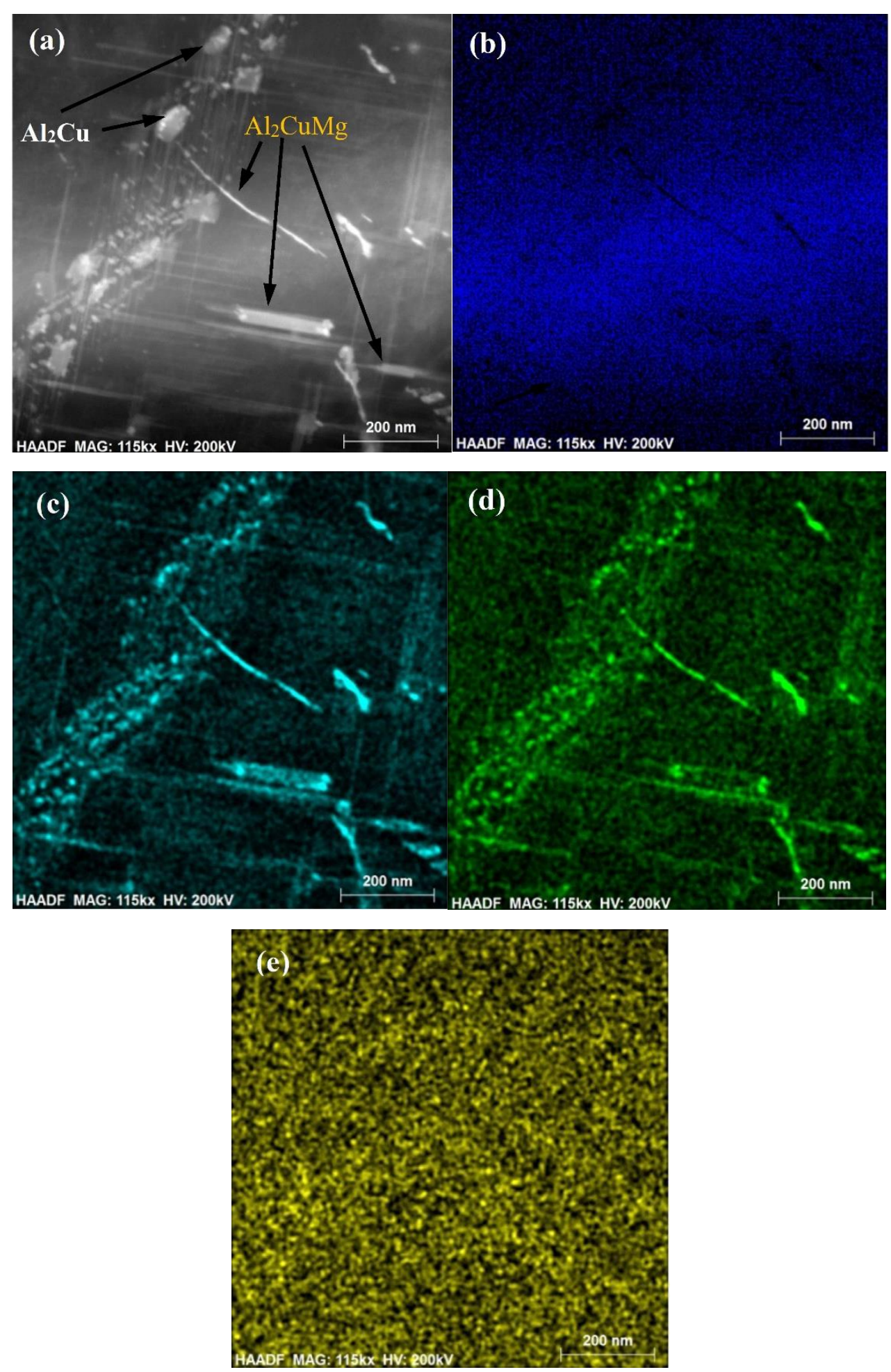

Figure 18. TEM and EDX of rheoformed 2024 aluminum matrix composite component reinforced by $5 \mathrm{vol} \% \mathrm{Al}_{2} \mathrm{O}_{3}$ nanoparticles at $620^{\circ} \mathrm{C}$ after T6 heat treatment (a) TEM image; (b) $\mathrm{Al}$; (c) $\mathrm{Cu}$; (d) $\mathrm{Mg}$; (e) $\mathrm{O}$. 
Figure 19 shows the XRD patterns of the rheoformed composite components with T6 and without T6 treatment. The XRD pattern of the rheoformed composite components without T6 showed the presence of the $\mathrm{Al}$ peaks, $\mathrm{Al}_{2} \mathrm{Cu}$ peaks, and $\mathrm{Al}_{2} \mathrm{O}_{3}$ peaks.

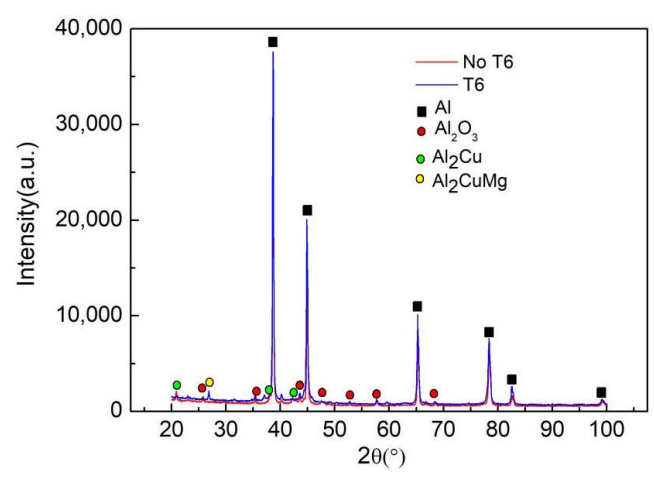

Figure 19. XRD analysis of rheoformed 2024 aluminum matrix composite component reinforced by $5 \mathrm{vol} \% \mathrm{Al}_{2} \mathrm{O}_{3}$ nanoparticles at $620^{\circ} \mathrm{C}$ for 25 min stirring time before and after T6 heat treatment.

$\mathrm{Al}_{2} \mathrm{CuMg}$ phase besides $\mathrm{Al}$ phase, $\mathrm{Al}_{2} \mathrm{Cu}$ phase, and $\mathrm{Al}_{2} \mathrm{O}_{3}$ nanoparticles was also detected in the XRD pattern of the rheoformed composite components with T6. It illustrates that more needle-like $\mathrm{Al}_{2} \mathrm{CuMg}$ phase besides short-rod-like $\mathrm{Al}_{2} \mathrm{Cu}$ phase precipitated in the rheoformed composite components with T6. As a result, mechanical properties of the rheoformed composite components with T6 were improved significantly as compared to the rheoformed composite components without T6.

\subsection{Wear Behavior of the Rheoformed Composite Components}

Figure 20 shows wear rate of the rheoformed composite components reinforced by different volume fraction $\mathrm{Al}_{2} \mathrm{O}_{3}$ nanoparticles at $620^{\circ} \mathrm{C}$ for 25 min stirring time. As shown in Figure 20, wear resistance of the rheoformed composite components increased significantly as compared to that of the rheoformed matrix components. Furthermore, wear resistance of the rheoformed composite components increased when volume fraction of $\mathrm{Al}_{2} \mathrm{O}_{3}$ nanoparticles increased from $1 \%$ to $7 \%$. The research of Alhawari et al. [46] also showed that wear resistance of the composite part formed via semisolid processing was higher than that of the composite part via conventional stirring casting. When volume fraction of $\mathrm{Al}_{2} \mathrm{O}_{3}$ nanoparticles reached $10 \%$, wear rate of the rheoformed composite components decreased slightly as compared to that of the rheoformed composite components with $5 \% \mathrm{Al}_{2} \mathrm{O}_{3}$ nanoparticles. Greater agglomeration of $\mathrm{Al}_{2} \mathrm{O}_{3}$ nanoparticles leads to difficult uniform dispersion of $\mathrm{Al}_{2} \mathrm{O}_{3}$ nanoparticles. It led to a decrease in effective dispersion of $\mathrm{Al}_{2} \mathrm{O}_{3}$ nanoparticles in the 2024 matrix, reducing wear resistance.

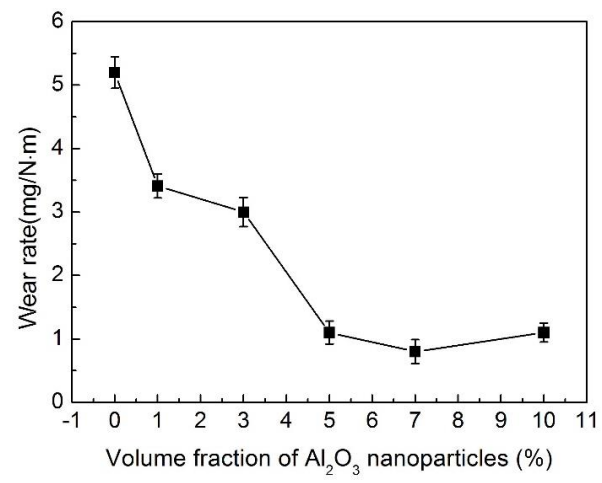

Figure 20. Wear rate of rheoformed 2024 aluminum matrix composite component reinforced by different volume fraction $\mathrm{Al}_{2} \mathrm{O}_{3}$ nanoparticles at $620{ }^{\circ} \mathrm{C}$ for $25 \mathrm{~min}$ stirring time. 
The specimens subjected to wear test have been examined via SEM (Figure 21). The surface exhibited some clear longitudinal abrasive grooves due to the ploughing effects of harder steel asperities. With an increase of volume fraction of $\mathrm{Al}_{2} \mathrm{O}_{3}$ nanoparticles, the depth of ploughing grooves became shallow. It indicates that the composite's resistance to wear increases. It is due to the fact that the increase in volume fraction of $\mathrm{Al}_{2} \mathrm{O}_{3}$ nanoparticles led to an increase in the hardness of the composite. Increase of the hardness of the material is beneficial to improve the resistance to wear [47]. In addition, a delamination was found in the microstructure of the worn surface. It illustrates that the dominant wear mechanism was a combination of adhesion and delamination mechanisms, similar to the findings of Alhawari [46].
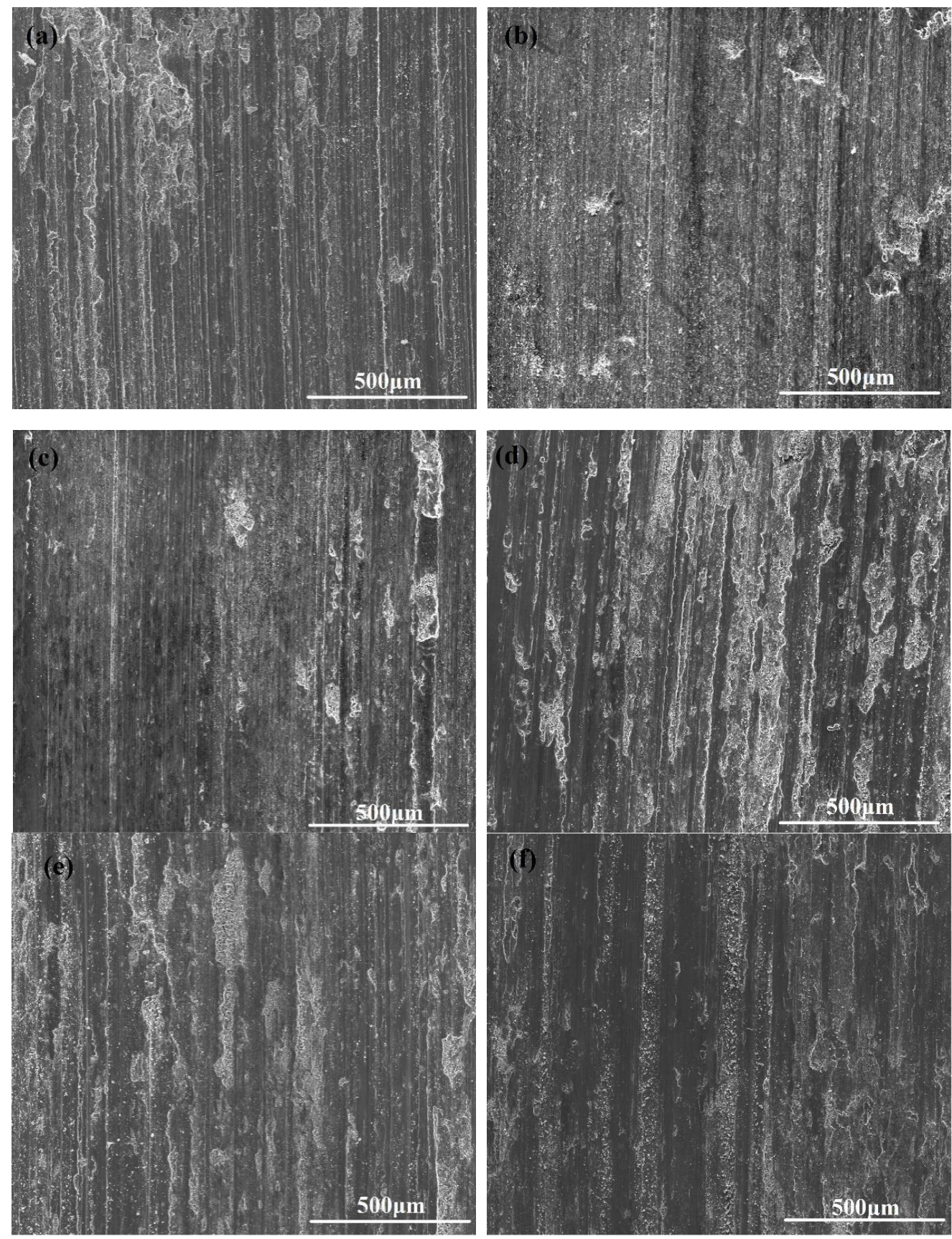

Figure 21. Wear morphology of rheoformed 2024 aluminum matrix composite component reinforced by $\mathrm{Al}_{2} \mathrm{O}_{3}$ nanoparticles with different volume fraction at $620^{\circ} \mathrm{C}$ for $25 \mathrm{~min}$ stirring time (a) 0 ; (b) $1 \%$; (c) $3 \%$; (d) $5 \%$; (e) $7 \%$; (f) $10 \%$. 


\section{Conclusions}

(1) 2024 aluminum matrix composite components reinforced by $\mathrm{Al}_{2} \mathrm{O}_{3}$ nanoparticles were rheoformed successfully. Complete filling status and good surface quality were achieved in the rheoformed composite components. Microstructure at the top and middle side wall consisted of near spheroidal grains and liquid phase, indicating dependence of deformation on liquid incorporating solid grains (FLS) and sliding between solid grains (SSG). However, obvious elongated grains were noted in the low side wall and at bottom of the rheoformed composite components. It illustrated that deformation in these locations was dominated by plastic deformation of solid grains (PDS).

(2) Mechanical properties of the rheoformed composite components were influenced by stirring temperature, stirring time, and volume fraction of $\mathrm{Al}_{2} \mathrm{O}_{3}$ nanoparticles of composite semisolid slurries. The optimal UTS of $358 \mathrm{MPa}$ and YS of $245 \mathrm{MPa}$ were obtained at the bottom of the rheoformed composite components with $5 \% \mathrm{Al}_{2} \mathrm{O}_{3}$ nanoparticles at $620{ }^{\circ} \mathrm{C}$ for 25 min stirring time. The increasing degrees of UTS are $17.5 \%$ and $31.7 \%$ as compared to the matrix component. Uniform dispersed $\mathrm{Al}_{2} \mathrm{O}_{3}$ nanoparticles and high density dislocations and dislocation tangles caused by PDS led to an improvement of mechanical properties. Needle-like $\mathrm{Al}_{2} \mathrm{CuMg}$ phase and short-rod-like $\mathrm{Al}_{2} \mathrm{Cu}$ phase were found in the microstructure of the rheoformed composite components due to natural ageing. $\mathrm{MgAl}_{2} \mathrm{O}_{4}$ phase has no effect on mechanical properties due to good wetting and high properties.

(3) T6 heat treatment led to an improvement of mechanical properties of the rheoformed composite components. UTS of 417MPa and YS of $328 \mathrm{MPa}$ were achieved at bottom of the rheoformed composite components with $5 \% \mathrm{Al}_{2} \mathrm{O}_{3}$ nanoparticles at $620{ }^{\circ} \mathrm{C}$ for 25 min stirring time. UTS, YS, and elongation of the composite components with T6 heat treatment were increased by $16.5 \%$, $20.6 \%$, and $5.6 \%$ respectively as compared to the composite component without $\mathrm{T} 6$ heat treatment. UTS and YS of the composite components with T6 heat treatment were increased by $36.7 \%$ and $49.1 \%$ respectively as compared to the matrix components with T6 heat treatment. Improvement of mechanical properties of the rheoformed composite components with T6 was attributed to a large amount of precipitated needle-like $\mathrm{Al}_{2} \mathrm{CuMg}$ phase and short-rod-like $\mathrm{Al}_{2} \mathrm{Cu}$ phase.

(4) Wear resistance of the rheoformed composite components increased as compared to that of the matrix component. Furthermore, wear resistance of the rheoformed composite components increased with an increase of $\mathrm{Al}_{2} \mathrm{O}_{3}$ nanoparticles from $1 \%$ to $7 \%$. A slight decrease in wear rate of the rheoformed composite components resulted from $10 \% \mathrm{Al}_{2} \mathrm{O}_{3}$ nanoparticles due to a decrease in effective dispersion of $\mathrm{Al}_{2} \mathrm{O}_{3}$ nanoparticles caused by greater agglomeration. The delamination and shallow ploughing grooves illustrate that the dominant wear mechanism was a combination mechanism of adhesion and delamination. To sum up, the optimal process parameters to obtain best comprehensive mechanical properties and resistance to wear are a stirring temperature of $620^{\circ} \mathrm{C}$, a stirring time of $25 \mathrm{~min}$, and a volume fraction of $5 \%$ nano-sized $\mathrm{Al}_{2} \mathrm{O}_{3}$ nanoparticles.

Author Contributions: J.J. designed most experiments, analyzed the results, and wrote this manuscript. G.X. and Y.L. performed most experiments. Y.W. helped analyze the experimental data and gave some constructive suggestions on this manuscript.

Funding: This research was funded by the Natural Science Foundation of China (NSFC) under Grant No. 51375112.

Conflicts of Interest: The authors declare no conflicts of interest.

\section{References}

1. Mandal, D.; Viswanathan, S. Effect of heat treatment on microstructure and interface of SiC particle reinforced $2124 \mathrm{Al}$ matrix composite. Mater. Charact. 2013, 85, 73-81. [CrossRef]

2. Mindivan, H.; Kayali, E.S.; Cimenoglu, H. Tribological behavior of squeeze cast aluminum matrix composites. Wear 2008, 265, 645-654. [CrossRef] 
3. Bharath, V.; Nagaral, M.; Auradi, V.; Kori, S.A. Preparation of $6061 \mathrm{Al}-\mathrm{Al}_{2} \mathrm{O}_{3} \mathrm{MMC}^{\prime}$ s by stir casting and evaluation of mechanical and wear properties. Procedia Mater. Sci. 2014, 6, 1658-1667. [CrossRef]

4. Natarajan, N.; Vijayarangan, S.; Rajendran, I. Wear behaviour of A356/25SiC aluminium matrix composites sliding against automobile friction material. Wear 2006, 261, 812-822. [CrossRef]

5. Prabu, S.B.; Karunamoorthy, L.; Kathiresan, S.; Mohan, B. Influence of stirring speed and stirring time on distribution of particles in cast metal matrix composite. J. Mater. Process. Technol. 2006, 171, 268-273. [CrossRef]

6. Tjong, S.C.; Ma, Z.Y. High-temperature creep behaviour of powder-metallurgy aluminium composites reinforced with $\mathrm{SiC}$ particles of various sizes. Compos. Sci. Technol. 1999, 59, 1117-1125. [CrossRef]

7. Bajpai, G.; Purohit, R.; Rana, R.S.; Rajpurohit, S.S.; Rana, A. Investigation and testing of mechanical properties of Al-nano $\mathrm{SiC}$ composites through cold isostatic compaction process. Mater. Today Proc. 2017, 4, 2723-2732. [CrossRef]

8. Tatar, C.; Özdemir, N. Investigation of thermal conductivity and microstructure of the $\alpha-\mathrm{Al}_{2} \mathrm{O}_{3}$ particulate reinforced aluminum composites $\left(\mathrm{Al} / \mathrm{Al}_{2} \mathrm{O}_{3}-\mathrm{MMC}\right)$ by powder metallurgy method. Phys. $B$ Condensed Matter 2010, 405, 896-899. [CrossRef]

9. Zhang, Q.; Wu, G.H.; Chen, G.Q.; Jiang, L.T.; Luan, B.F. The thermal expansion and mechanical properties of high reinforcement content $\mathrm{SiCp} / \mathrm{Al}$ composites fabricated by squeeze casting technology. Compos. Part A-Appl. S. 2003, 34, 1023-1027. [CrossRef]

10. Chou, S.N.; Huang, J.L.; Lii, D.F.; Lu, H.H. The mechanical properties of $\mathrm{Al}_{2} \mathrm{O}_{3}$ /aluminum alloy A356 composite manufactured by squeeze casting. J. Alloy. Compd. 2006, 419, 98-102. [CrossRef]

11. Chen, W.P.; Liu, Y.X.; Yang, C.; Zhu, D.Z.; Li, Y.Y. (SiCp + Ti)/7075Al hybrid composites with high strength and large plasticity fabricated by squeeze casting. Mater. Sci. Eng. A 2014, 609, 250-254. [CrossRef]

12. Wang, L.; Qiu, F.; Zou, Q.; Yang, D.L.; Tang, J.; Gao, Y.Y.; Li, Q.; Han, X.; Shu, S.L.; Chang, F.; et al. Microstructures and tensile properties of nano-sized $\mathrm{SiC}_{\mathrm{p}} / \mathrm{Al}-\mathrm{Cu}$ composites fabricated by semisolid stirring assisted with hot extrusion. Mater. Charact. 2017, 131, 195-200. [CrossRef]

13. Guan, L.N.; Geng, L.; Zhang, H.W.; Huang, L.J. Effects of stirring parameters on microstructure and tensile properties of $\left(\mathrm{ABO}_{\mathrm{w}}+\mathrm{SiC}_{\mathrm{p}}\right) / 6061 \mathrm{Al}$ composites fabricated by semi-solid stirring technique. Trans. Nonferrous Met. Soc. China 2011, 21, s274-s279. [CrossRef]

14. Sameer, K.D.; Sumanm, K.N.S.; Tara, S.C.; Ravindra, K.; Palash, P.; Venkata, S.S.B. Microstructure, mechanical response and fractography of $\mathrm{AZ91E} / \mathrm{Al}_{2} \mathrm{O}_{3}(\mathrm{p})$ nano composite fabricated by semi solid stir casting method. J. Magn. Alloys 2017, 5, 48-55.

15. Prashanth, K.G.; Scudino, S.; Chaubey, A.K.; Löber, L.; Wang, P.; Attar, H.; Schimansky, F.P.; Pyczak, F.; Eckert, J. Processing of Al-12Si-TNM composites by selective laser melting and evaluation of compressive and wear properties. J. Mater. Res. 2016, 31, 55-65. [CrossRef]

16. Prashantha, K.G.; Shahabia, H.S.; Attara, H.; Srivastavac, V.C.; Ellendtd, N.; Uhlenwinkeld, V.; Eckerta, J.; Scudino, S. Production of high strength $\mathrm{Al}_{85} \mathrm{Nd}_{8} \mathrm{Ni}_{5} \mathrm{Co}_{2}$ alloy by selective laser melting. Addit. Manuf. 2015, 6, 1-5. [CrossRef]

17. Attar, H.; Bönisch, M.; Calin, M.; Zhang, L.C.; Scudino, S.; Eckert, J. Selective laser melting of in situ titanium-Titanium boride composites: Processing, microstructure and mechanical properties. Acta Mater. 2014, 76, 13-22. [CrossRef]

18. Cui, Y.N.; Wang, L.F.; Ren, J.Y. Multi-functional SiC/Al Composites for aerospace applications. Chin. J. Aeronaut. 2008, 21, 578-584.

19. Lee, S.S.; Yeo, J.S.; Hong, S.H.; Yoon, D.J.; Na, K.H. The fabrication process and mechanical properties of $\mathrm{SiCp} / \mathrm{Al}-\mathrm{Si}$ metal matrix composites for automobile air-conditioner compressor piston. J. Mater. Process. Technol. 2001, 113, 202-208. [CrossRef]

20. Koli, D.K.; Agnihotri, G.; Purohit, R. A review on properties, behaviour and processing methods for Al-nano $\mathrm{Al}_{2} \mathrm{O}_{3}$ composites. Procedia Mater. Sci. 2014, 6, 567-589. [CrossRef]

21. Raju, P.R.M.; Siriyala, R.; Raju, K.S.; Raju, R.V.R. Evaluation of fatigue life of $\mathrm{Al} 2024 / \mathrm{Al}_{2} \mathrm{O}_{3}$ particulate nano composite fabricated using stir casting technique. Mater. Today Proc. 2017, 4, 3188-3196. [CrossRef]

22. Raturi, A.; Mer, K.K.S.; Pant, P.K. Synthesis and characterization of mechanical, tribological and micro structural behaviour of $\mathrm{Al} 7075$ matrix reinforced with nano $\mathrm{Al}_{2} \mathrm{O}_{3}$ particles. Mater. Today Proc. 2017, 4, 2645-2658. [CrossRef] 
23. Sajjadi, S.A.; Parizi, M.T.; Ezatpour, H.R.; Sedghi, A. Fabrication of A356 composite reinforced with micro and nano $\mathrm{Al}_{2} \mathrm{O}_{3}$ particles by a developed compocasting method and study of its properties. J. Alloy. Compd. 2012, 511, 226-231. [CrossRef]

24. Akbari, M.K.; Baharvandi, H.R.; Mirzaee, O. Fabrication of nano-sized $\mathrm{Al}_{2} \mathrm{O}_{3}$ reinforced casting aluminum composite focusing on preparation process of reinforcement powders and evaluation of its properties. Compos. Part B-Eng. 2013, 55, 426-432. [CrossRef]

25. Akbari, M.K.; Baharvandi, H.R.; Mirzaee, O. Nano-sized aluminum oxide reinforced commercial casting A356 alloy matrix: Evaluation of hardness, wear resistance and compressive strength focusing on particle distribution in aluminum matrix. Compos. Part B-Eng. 2013, 52, 262-268. [CrossRef]

26. Yang, Y.; Lan, J.; Li, X.C. Study on bulk aluminum matrix nano-composite fabricated by ultrasonic dispersion of nano-sized SiC particles in molten aluminum alloy. Mater. Sci. Eng. A 2004, 380, 378-383. [CrossRef]

27. Kandemir, S.; Atkinson, H.V.; Weston, D.P.; Hainsworth, S.V. Thixoforming of A356/SiC and A356/TiB 2 nanocomposites fabricated by a combination of green compact nanoparticle incorporation and ultrasonic treatment of the melted compact. Metall. Mater. Trans. A 2014, 45, 5782-5798. [CrossRef]

28. Jiang, J.F.; Wang, Y. Microstructure and mechanical properties of the rheoformed cylindrical part of 7075 aluminum matrix composite reinforced with nano-sized SiC particles. Mater. Des. 2015, 79, 32-41. [CrossRef]

29. Kandemir, S. Microstructure and mechonicol properties of A357/SiC nonocomposites fobricated by ultrosonic covitotion-based dispersion of ball-milled nonoparticles. J. Compo. Mater. 2017, 51, 395-404. [CrossRef]

30. ASTM Standard E8M. Standard Test Methods for Tension Testing of Metallic Materials [Metric]; ASTM International: West Conshohocken, PA, USA, 2008.

31. Chen, C.P.; Tsao, C.-Y.A. Semi-solid deformation of non-dendrtic structure-I. Phemonological behavior. Acta Mater. 1997, 45, 1955-1968. [CrossRef]

32. Kubotak, K.; Mabuchi, M.; Higashi, K. Review processing and mechanical properties of fine-grained Mg alloys. J. Mater. Sci. 1999, 34, 2255-2262. [CrossRef]

33. Sajjadi, S.A.; Ezatpour, H.R.; Beygi, H. Microstructure and mechanical properties of $\mathrm{Al}_{-} \mathrm{Al}_{2} \mathrm{O}_{3}$ micro and nanocomposites fabricated by stir casting. Mater. Sci. Eng. A 2011, 528, 8765-8771. [CrossRef]

34. Yar, A.A.; Montazerian, M.; Abdizadeh, H.; Baharvandi, H.R. Microstructure and mechanical properties of aluminum alloy matrix composite reinforced with nano-particle MgO. J. Alloy. Compd. 2009, 484, 400-404. [CrossRef]

35. Nguyen, Q.B.; Gupta, M. Enhancing compressive response of $\mathrm{AZ31B}$ using nano- $\mathrm{Al}_{2} \mathrm{O}_{3}$ and copper additions. J. Alloy. Compd. 2010, 490, 382-387. [CrossRef]

36. Sastry, S.; Krishnab, M.; Uchil, J. A study on damping behaviour of aluminite particulate reinforced ZA-27 alloy metal matrix composites. J. Alloy. Compd. 2001, 314, 268-274. [CrossRef]

37. Su, H.; Gao, W.L.; Feng, Z.H.; Lu, Z. Processing, microstructure and tensile properties of nano-sized $\mathrm{Al}_{2} \mathrm{O}_{3}$ particle reinforced aluminum matrix composites. Mater. Des. 2012, 36, 590-596. [CrossRef]

38. Zhong, X.L.; Wong, W.L.E.; Gupta, M. Enhancing strength and ductility of magnesium by integrating it with aluminum nanoparticles. Acta Mater. 2007, 55, 6338-6344. [CrossRef]

39. Ghidelli, M.; Sebastiani, M.; Collet, C.; Guillemet, R. Determination of the elasticmoduli and residual stresses of freestanding Au-TiW bilayer thin films by nanoindentation. Mater. Des. 2016, 106, 436-445. [CrossRef]

40. Ghidelli, M.; Sebastiani, M.; Johanns, K.E.; Pharr, G.M. Effects of indenter angle on micro-scale fracture toughness measurement by pillar splitting. J. Am. Ceram. Soc. 2017, 100, 5731-5738. [CrossRef]

41. Mazahery, A.; Abdizadeh, H.; Baharvandi, H.R. Development of high-performance $\mathrm{A} 356 / \mathrm{nano}-\mathrm{Al}_{2} \mathrm{O}_{3}$ composites. Mater. Sci. Eng. A 2009, 518, 61-64. [CrossRef]

42. Lan, J.; Yang, Y.; Li, X.C. Microstructure and microhardness of SiC nanoparticles reinforced magnesium composites fabricated by ultrasonic method. Mater. Sci. Eng. A 2004, 386, 284-290. [CrossRef]

43. Korgul, P.; Wilson, D.R.; Lee, W.E. Microstructural analysis of corroded alumina-spine1 castable refractories. J. Eur. Ceram. Soc. 1997, 17, 77-84. [CrossRef]

44. Ghosha, A.; Sarkar, R.; Mukerjee, B.; Das, S.K. Effect of spinel content on the properties of magnesia-spinel composite refractory. J. Eur. Ceram. Soc. 2004, 24, 2079-2085. [CrossRef]

45. Zang, J. Wetting and Adhesion at $\mathrm{Al} / \mathrm{MgAl} 2 \mathrm{O} 4$ Interface and the Effect of Substrate Crystallographic Orientation. Ph.D. Thesis, Jilin University, Changchun, China, 2014. 
46. Alhawari, K.S.; Omar, M.Z.; Ghazali, M.J.; Salleh, M.S.; Mohammed, M.N. Wear properties of $\mathrm{A}_{356} / \mathrm{Al}_{2} \mathrm{O}_{3}$ metal matrix composites produced by semisolid processing. Procedia Eng. 2013, 68, 186-192. [CrossRef]

47. Ehtemam-Haghighi, S.; Prashanthb, K.G.; Attar, H.; Chaubey, A.K.; Caod, G.H.; Zhang, L.C. Evaluation of mechanical and wear properties of Ti-xNb-7Fe alloys designed for biomedical applications. Mater. Des. 2016, 111, 592-599. [CrossRef] 